\begin{abstract}
UNIVERSIDADE DE BRASÍLIA - UNB
CENTRO DE EXCELÊNCIA EM TURISMO

CURSO DE ESPECIALIZAÇÃO PARA PROFESSORES E PESQUISADORES EM

TURISMO E HOSPITALIDADE
\end{abstract}

\title{
O SETOR EXPLORATÓRIO MIGRATÓRIO COM ENFOQUE EM AGÊNCIAS DE VIAGENS DE GOIÂNIA
}

Marcos Pereira de Souza

Goiânia - GO

Janeiro - 2004 
UNIVERSIDADE DE BRASÍLIA - UNB

CENTRO DE EXCELÊNCIA EM TURISMO

CURSO DE ESPECIALIZAÇÃO PARA PROFESSORES E PESQUISADORES EM TURISMO E HOSPITALIDADE

\title{
O SETOR EXPLORATÓRIO MIGRATÓRIO COM ENFOQUE EM AGÊNCIAS DE VIAGENS DE GOIÂNIA
}

\author{
Monografia apresentada à Universidade de Brasília - UNB, como \\ exigência para obtenção do título lato senso de especialista no curso \\ de especialização para professores e pesquisadores em turismo e \\ hospitalidade.
}

Orientadora: Profa. Dra. Ellen Fensterseiter Woortmann

Marcos Pereira de Souza

Goiânia - GO
Janeiro - 2004 
SOUZA, Marcos Pereira de. O setor exploratório migratório com enfoque em agências de viagens de Goiânia. Goiânia: UNB, 2004, XX p. Monografia de especialização para professores e pesquisadores em turismo e hospitalidade.

\section{BANCA EXAMINADORA}

Profa. Orientadora Dra. Ellen Fensterseiter Woortmann

Profa. Membro Cléria Botelho da Costa

Defesa da monografia

Conceito:

Em:................................... 


\section{DEDICATÓRIA}

Diante da luta travada no decorrer do curso, sempre houve pessoas que me ajudaram a sustentar firmemente esta proposta e manter o incentivo para conseguirmos a vitória. Dedico esta obra aos meus mestres, colegas de profissão e entes queridos. 
AGRADECIMENTO

A Deus, pela força interior nesta trajetória.

Às agências de viagem pela atenção e ajuda.

Aos funcionários que contribuíram com informações.

À professora Tânia pela direção e caminho oferecido. 


\section{SUMÁRIO}

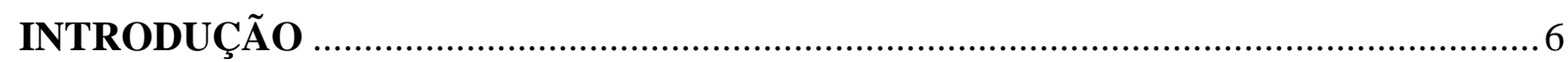

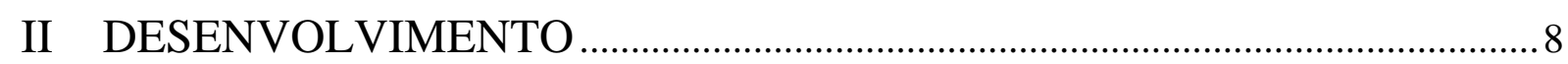

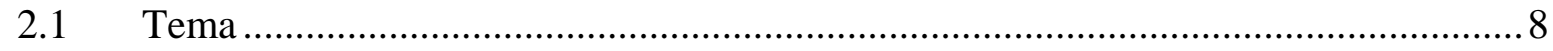

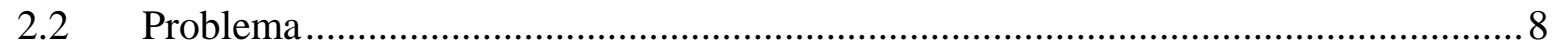

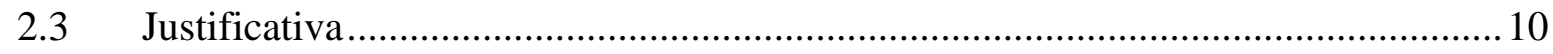

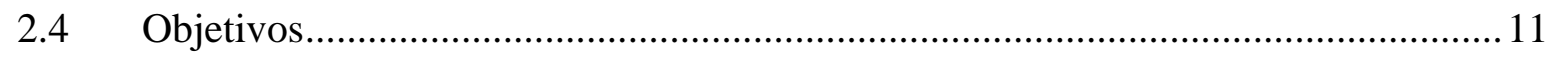

2.4.1 Objetivo Geral ..................................................................................11

2.4.2 Objetivos Específicos ............................................................................. 11

2.5 Metodologia.................................................................................................. 12

2.5.1 Abordagem Metodológica ………………………………………………....... 12

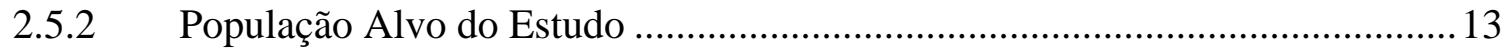

2.5.3 Plano de Amostragem.................................................................................... 14

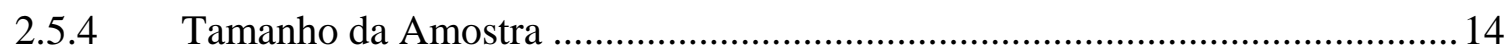

2.5.5 Método de Coleta de Dados ....................................................................... 15

2.5.5.1 Método Exploratório …………………………………………………..... 15

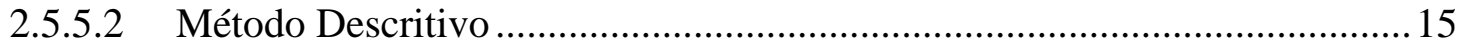

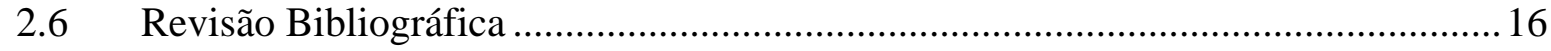

2.6.1 Migração Internacional e o Capitalismo - Breve Histórico .................................16

2.6.2 Migração e Tráfico de Seres Humanos................................................................... 32

2.6.2.1 Estatísticas da Emigração Mundial ..............................................................32

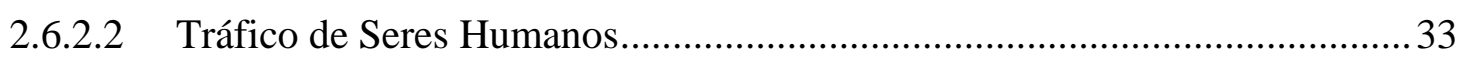

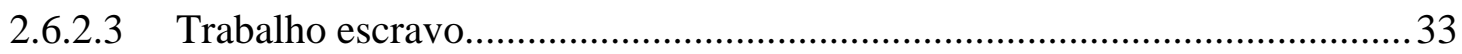

2.6.2.4 Tráfico de Crianças..................................................................................... 34

2.6.2.5 Tráfico de Mulheres.....................................................................................34

2.6.2.6 A Imigração e as Suas Causas ........................................................................ 35

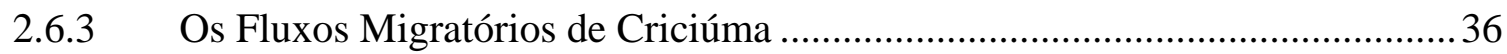

2.6.3.1 Partindo de Criciúma: tecendo redes familiares e de gênero rumo aos estados unidos. 37

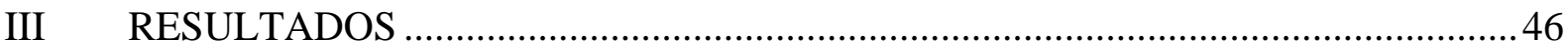

CONCLUSÃO

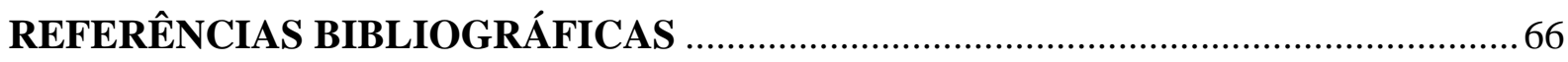

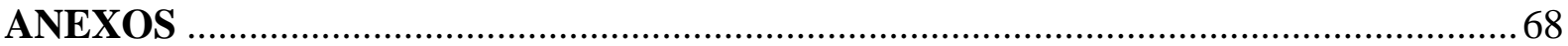




\section{INTRODUÇÃO}

Durante décadas os fluxos migratórios de brasileiros para países economicamente mais ricos se intensificaram frente às altas taxas de desemprego e ao estado deplorável da pobreza urbana. Na expectativa de galgar novos horizontes, o cidadão do Brasil tem se arriscado em viagens aventureiras para os Estados Unidos via México, onde muitas vezes suas próprias vidas são colocadas em risco pelos atravessadores, conhecidos no meio como “coyotes”.

Segundo Brito (1995),

Ao contrário do que ocorreu na Segunda Revolução Industrial, os fluxos migratórios que se intensificam agora são no sentido da periferia para o centro do capitalismo, ou dos países em desenvolvimento para os mais desenvolvidos. Mesmo porque, as condições sociais, econômicas e demográficas dos países mais pobres estão longe de exercerem a mesma atração de um século atrás.

Nesse sentido, o turismo do país vem sofrendo uma série de enganos, por absorver em seu bojo um elenco de dados incapazes de retratar a realidade. Quando se busca observar os fluxos migratórios internacionais e utilizar suas estatísticas como fonte de planejamento, acaba-se por construir dimensionamentos irreais; o que pode representar um mau investimento e até mesmo a desestruturação dos investidores e profissionais em turismo.

Sabe-se das dificuldades encontradas por brasileiros que almejam um visto para embarcarem rumo ao mencionado país. Assim, não lhes restam outras opções, senão, a de pisarem em território americano de forma ilegal, acarretando uma série de fatos, como a mencionada deficiência das estatísticas oficiais, pela falta de registro; a intensificação de vendas de passagens aéreas, causando nas agências a falsa impressão de que este seria um fluxo constante destinado ao turismo.

Partindo destas premissas, as agências de viagem de Goiânia vêm sofrendo, durante este processo, uma remodelagem de suas estruturas e uma tendência natural de focar seus negócios em receitas oriundas de fluxos migratórios para os EUA via México, ou seja, em um nicho de mercado altamente arriscado e sujeito a um súbito fim, caso ocorra uma intensificação das fiscalizações pelas as nações envolvidas nesse processo. 
Diante do exposto, a presente pesquisa se propõe a analisar esses fluxos; identificar sua sazonalidade; traçar o perfil das pessoas que decidiram por migrarem para os EUA via México, seus conhecimentos sobre os riscos e os principais motivos que levaram a tal decisão; verificar como reagem as agências de viagem de Goiânia que operam neste filão e verificar como estes dados aparecem nas estatísticas oficiais. 


\section{DESENVOLVIMENTO}

\subsection{Tema}

O setor exploratório migratório com enfoque nas agências de viagem de Goiânia.

É fato que desde a década de cinqüenta o cidadão brasileiro, devido à crise financeira encontrada no País e a falta de oportunidades de trabalho, tende a se deslocar para países de primeiro mundo em busca de novos horizontes de trabalho e melhores condições de vida.

Considerando todo um know how adquirido em 18 anos de trabalho em agências de viagens, esses fatos migratórios têm despertado inúmeras indagações, pois, a cada ano, esse fenômeno social turístico cresce a índices alarmantes. Não é raro observar famílias inteiras deixando o País rumo a "terra prometida", como bem demonstram os meios de comunicação.

Tomando como base específica uma Agência de Viagens de Goiânia, foi possível observar que cerca de 70\% de sua receita de pacotes de viagens bem como passagens aéreas internacionais são oriundas de vendas a pessoas que deixam o País com este objetivo. Logo, é de se imaginar que esses fatos têm camuflado as realidades estatísticas, social e turística dos órgãos oficiais no que se refere à pesquisa de passageiros que deixam o Brasil para fazer 
turismo no exterior. Ademais, cria-se um mundo paralelo de milhares de dólares, beneficiando de forma direta e indireta agentes de viagens, guias turísticos, atravessadores, do Brasil e exterior.

Assim, considerando as correntes migratórias do Brasil via México para os Estados Unidos e enfocando a clientela de Agências de viagens de Goiânia,

Qual é o impacto no faturamento de agências de viagens, qual a sazonalidade desses fluxos e como esta prática se reflete nas estatísticas dos órgãos oficiais de turismo? 


\section{$2.3 \quad$ Justificativa}

O estudo representará uma importante fonte real de pesquisa no que se refere a situação das agências de viagens de Goiânia quanto ao fenômeno das correntes migratórias para os Estados Unidos via México. Considerando os números alarmantes sobre migração para os Estados unidos, Brito (1995) afirma que "nos Estados Unidos entraram, durante a década de 1980, 7.338.000 migrantes legais, oriundos principalmente de países em desenvolvimento. Considerando a enorme entrada de imigrantes ilegais, estima-se para a década passada um fluxo de imigrantes de cerca de 10 milhões.” Nesse sentindo, verificar os impactos desse pseudoturismo torna-se uma importante tarefa para o mercado de Goiânia, uma vez que as entradas estrangeiras nos EUA por goianos têm ocorrido utilizando-se o pretexto do turismo, o que acaba por gerar falsas estatísticas e falso crescimento dos negócios, já que, uma vez combatido, estima-se que implicará na quebra de 70\% das agências de viagens.

Considerando como exemplo o caso de Governador Valadares, estima-se que entre os anos de 1990 a 1991 ocorreu a migração de aproximadamente 900.000 pessoas para os EUA, o que é um dado alarmante e fomenta a discussão da real situação de outras cidades do país, tal como Goiânia.

Além disso, como bem pôde ser observado na atualidade, tem surgido uma série de impasses e problemas entre o Brasil e os EUA no que se refere a esse tema, como bem retratou os meios de comunicação no último mês (VEJA, 2003) onde foi possível observar uma grande quantia de brasileiros presos na fronteira com o México por tentarem a migração ilegal. Sem contar na questão dos aeroportos, em que o Brasil está incluído na relação dos 25 países que oferecem risco de entradas terroristas naquela nação. Daí, este estudo torna-se amplamente viável por poder ofertar ao mercado de agências de Goiânia um estudo real e informativo sobre os riscos deste negócio. 


\section{$2.4 \quad$ Objetivos}

\subsubsection{Objetivo Geral}

Compreender e identificar a sozonalidade dos fluxos migratórios para os Estados Unidos, via México, por goianos, o seu impacto financeiro nas agências de viagem de Goiânia e sua representatividade nas estatísticas oficiais.

2.4.2 Objetivos Específicos

- Identificar a opinião de migrantes e suas famílias;

- Identificar opiniões de agentes de viagem;

- Identificar opiniões de atravessadores;

- Verificar as estatísticas oficiais;

- Pesquisar o fluxo deste mercado junto as agências de viagens. 


\section{$2.5 \quad$ Metodologia}

\subsubsection{Abordagem Metodológica}

A definição do método de pesquisa depende, em muitas vezes, de sua natureza, bem como do conhecimento, por parte do pesquisador, da população que será pesquisada. Dessa forma, quando se trata de projetos oriundos de pesquisas de campo e que possui em sua composição o registro da opinião de determinados extratos ou grupos de uma dada população, torna-se importante optar, dentro do possível, pelo melhor método capaz de representar a realidade pesquisada.

Da mesma forma, Roesh (1996, p. 120) complementa:

Se o projeto se refere a uma pesquisa de mercado sobre algum aspecto do ambiente, como é usual na área de marketing (por exemplo, pesquisas com clientes, competidores e fornecedores) deve ser apresentada uma descrição da população-alvo potencial. Nestes casos, é importante especificar também o plano de amostragem.

Para tanto, considerando que o estudo necessitou de dois momentos: revisão da literatura e pesquisa de campo, utilizou-se respectivamente os métodos, exploratório e descritivo.

Álvares (2001, p. 34 a 37), conceitua os dois métodos acima citados, com o seguinte: “Os estudos exploratórios são realizados a partir de dados secundários (já disponíveis): consulta a livros, jornais, publicações, pesquisas já realizadas, conversas informais com pessoas especializadas, etc.” Ou seja, este método permite que se faça uma revisão de toda literatura que envolve o tema em discussão, permitindo que se faça o entrelaçamento entre a teoria e prática. “A pesquisa descritiva destina-se a descrever as características de uma determinada situação a partir de dados primários, obtidos originalmente por meio de entrevistas pessoais ou discussões em grupo.”

Roesh (1996, p. 129) complementa:

Pesquisas de caráter descritivo não procuram explicar alguma coisa ou mostrar relações causais, como as pesquisas de caráter experimental. Censos, levantamentos de opinião pública ou pesquisas de mercado procuram fatos descritivos; buscam informação necessária para a ação ou predição. Pesquisas descritivas não respondem bem ao por que, embora possam associar certos resultados a grupos de respondentes. 
No método exploratório, serão levantados conteúdos de fontes de dados secundários (ou seja, já disponíveis), livros técnicos sobre fluxos migratórios internacionais; publicações, revistas de turismo e seus órgãos representativos, artigos científicos, investigação de estudos já realizados e internet. Esta será a fase de composição de fundamentação teórica.

No método descritivo, será utilizado o estudo do tipo quantitativo estatístico, ou levantamento de campo, que conforme Álvares (2001, p. 37) “(...) procura ter dados representativos da população de interesse se caracterizando pela pouca profundidade dos levantamentos e a grande amplitude, através de amostras representativas e sumários estatísticos.”

\subsubsection{População Alvo do Estudo}

Na pesquisa de satisfação do cliente, torna-se necessário definir qual a população a ser pesquisada.

Trata-se, o estudo, de pesquisa aplicada a emigrantes, agentes de viagem e atravessadores “coyotes”1, e por esta natureza, não há condições de se ter uma relação de toda população e suas relações. Novamente, Roesh (1996, p. 131) comenta:

Nem sempre é possível obter uma amostra representativa, ou seja, uma que possua as mesmas características da população, mas que seja menor em número. Por exemplo, muitas vezes deseja-se estudar uma população cujo tamanho e características demográficas (distribuição de idade, status socioeconômico, sexo, estado civil) são desconhecidos, ou seja, não existe um cadastro desta população e, portanto, não há condições de contatar estas pessoas em termos práticos. Oppenheim (1993, apud ROESH, 1996) aponta um enfoque para solucionar este problema: utilizar amostra de julgamento ou amostra intencional.

Portanto, para a aplicação do questionário da pesquisa, serão considerados os seguintes extratos da população em estudo:

\footnotetext{
${ }^{1}$ Coyotes - Termo utilizado para representar pessoas que propiciam a travessia de emigrantes ilegais para os Estados Unidos através do deserto entre o México e este País. O termo é utilizado por analogia, em função de que o coyote é um animal que habita esse local.
} 
- Agências de viagens de cidade de Goiânia, considerando as com estabilidade e estrutura e que atuam no nicho de passagens aéreas a migrantes via México.

- Atravessadores (coyotes), aqui entendidos como as pessoas que favorecem o esquema de migração via México (essa entrevista foi possível em função de que o pesquisador deste projeto atua no ramo de Agências de Viagens e possui penetração neste mercado).

- Cidadãos que já estão em processo de migração, ou seja, que já adquiriram seus bilhetes aéreos.

\subsubsection{Plano de Amostragem}

Considerando a natureza da população, bem como a dificuldade de delimitá-la, utilizar-se-á uma amostra não-probabilística por conveniência. Aquela em que a seleção dos elementos da população (universo) para compor a amostra depende, ao menos em parte, do julgamento do pesquisador ou do entrevistador (escolha do entrevistado). São usadas quando o resultado da pesquisa não precisa refletir a opinião de todo o Universo, quando os recursos financeiros, materiais, humanos e de tempo para a realização da pesquisa são escassos e quando todo o universo estudado não está disponível para ser sorteado. Como esclarece Cobra (1992; p:185) “Na amostragem não probabilística, não há sorteio, e as unidades são escolhidas por conveniência". Portanto o elemento pesquisado foi selecionado por estar disponível no local e no momento em que a pesquisa estava sendo realizada.

\subsubsection{Tamanho da Amostra}

- Agências de viagens de cidade de Goiânia - 15 unidades

- Emigrantes - 16 pessoas

- Atravessadores (coyotes) - 03 pessoas (considerando a dificuldade de conseguir este tipo de entrevista) 
Para ter uma coleta mais precisa, além da delimitação de amostra já definida acima, aleatoriamente as pessoas pesquisadas serão escolhidas em dias diferentes para se poder obter uma resposta mais representativa.

Para a fundamentação teórica utilizou-se o método exploratório de pesquisa para levantamento dos conteúdos já existentes sobre o tema "Fluxos migratórios internacionais" em: livros, revistas, jornais, internet.

\subsubsection{Método de Coleta de Dados}

\subsubsection{Método Exploratório}

Levantamento em Fontes Secundárias: sob o qual se estruturará a fundamentação teórica do estudo. Nesta fase, serão colhidos dados importantes para e justificar as análises da parte prática, laçando mão de livros técnicos, jornais, revistas, internet e toda fonte de informação escrita.

Inquérito Pessoal: buscar-se-á informações sobre os dados de turismo da cidade, em empresas/instituições como SEBRAE, EMBRATUR, ABAV, ou outras agências colaboradoras.

\subsubsection{Método Descritivo}

Os estudos serão de natureza quantitativa estatística, por se tratar de uma pesquisa objetiva em três populações finitas extratificadas. Para tanto, lançando mão do método de inquérito pessoal estes extratos ou amostras da população serão entrevistados por meio de três questionários contendo questões abertas. 


\subsection{Revisão Bibliográfica}

\subsubsection{Migração Internacional e o Capitalismo - Breve Histórico}

Para se ter uma visão geral sobre as questões históricas que envolvem os fluxos migratórios internacionais é preciso buscar as relações existentes entre eles e o capitalismo. Buscar análises consistentes sobre esses fatos não costuma ser uma tarefa fácil, entretanto, Brito (1995) apresenta um artigo que procura englobar todo esse processo, como segue.

Uma das características da história do capitalismo tem sido a intensa mobilidade espacial da população. Dentro de cada país, as cidades se transformaram em locus hegemônico da acumulação de capital, acelerando os processos de urbanização, fruto não só do crescimento vegetativo da população mas, principalmente, das migrações internas originárias do campo. Cada país, é claro, tem a sua própria história e, portanto, processos específicos de desenvolvimento, urbanização e mobilidade espacial da população. Entretanto, não houve economia e sociedade que se desenvolvessem sem que houvesse uma intensa mobilidade espacial da população.

Mas estas migrações também ocorrem entre os diferentes países, constituindo um outro traço do desenvolvimento do capitalismo. Há um permanente fluxo internacional de população que, em determinadas circunstâncias, tem se acentuado. A história recente não poderia ser bem compreendida se não fosse considerada a interação entre os países através das suas populações. A própria identidade de muitos deles, a sua constituição como nação, foi um produto do movimento internacional de diferentes povos.

Os países das Américas, o chamado Novo Mundo, têm a sua formação fortemente marcada pelas migrações internacionais. Inseridos no “Antigo Sistema Colonial“, 
foram a confluência dos povos europeus, africanos e asiáticos. No Brasil, a presença do colonizador português se intensificou no século XVIII, a partir da economia da mineração, que também ampliou o fluxo de escravos africanos. Outros europeus, franceses e holandeses, colonizadores ávidos por novas terras e produtos, já haviam marcado a sua presença aqui, principalmente nas regiões Norte e Nordeste. Mas foram basicamente portugueses e africanos - somados aos povos indígenas - quem criaram as bases da sociedade brasileira que se configurava no período colonial (Novais, 1979).

O Estado e a nação brasileiros se consolidaram no século passado, a partir de 1822, momento em que o capitalismo emergente na Inglaterra buscava ampliar os mercados para sua produção - inicialmente a indústria têxtil e, depois, máquinas, bens intermediários e de consumo durável. Não haveria capitalismo sem a articulação internacional dos mercados. O Antigo Sistema Colonial havia promovido uma integração internacional, comandada pelo capital mercantil das metrópoles, consoante com as rígidas normas dos monopólios e do exclusivo comercial. O próprio movimento das pessoas, escravos e homens livres, obedecia a este rígido controle.

O capitalismo inglês, hegemônico internacionalmente, exigiu liberdade de comércio para as mercadorias e recursos financeiros, rompendo as rédeas dos monopólios e do exclusivo comercial. Como conseqüência, o século XIX assistiu a uma movimentação internacional de população, principalmente na sua segunda metade. Convém lembrar que o Brasil, apesar das pressões dos ingleses, manteve a escravidão, da qual dependia a economia cafeeira, até 1888, embora o fluxo internacional de escravos tivesse praticamente se extinguido desde 1850. Já nesta época, o governo do Império começava a promover uma política deliberada de atração de imigrantes internacionais, como foi o caso da colonização alemã no sul do país. Os objetivos desta política eram não só a ocupação do espaço, criandose núcleos de colonização, mas também a miscigenação da população segundo o padrão racial europeu.

Na Inglaterra, a emergência da chamada Primeira Revolução Industrial levou a uma aceleração do crescimento demográfico, que tinha se mantido estável ao longo do período 1650-1750, com a população em torno de 6 milhões de habitantes. Em 1800 a população inglesa já alcançava cerca de 9 milhões de habitantes. Não só a Inglaterra, mas a Europa de uma maneira geral viveu no século XIX os seus diferentes processos de transição demográfica. Durante a primeira metade do século houve uma aceleração do crescimento 
demográfico, com o aumento das taxas de fecundidade, que já no final do Oitocentos tenderam a declinar, reduzindo o ímpeto do aumento populacional. A Inglaterra alcançou o seu maior crescimento entre 1811 e 1821, com taxas geométricas médias anuais de 1,67\% ( Wrigley, 1979 ).

Mas foi só na segunda metade do século passado que as emigrações européias se tornaram mais relevantes, em função das profundas mudanças por que passava o capitalismo com a Segunda Revolução Industrial. Ocorridas ainda sob o domínio inglês, mas se estendendo ao continente europeu, além dos Estados Unidos e Japão, estas transformações reestruturaram o capitalismo. Na sua emergência, a economia capitalista tinha uma dinâmica que se caracterizava pela concorrência através dos preços, precisando da incorporação crescente de mercados. Em torno de 1840, ela começou a dar sinais de crise em razão de sua vulnerabilidade à formação de "excedentes na oferta de mercadorias". A saída foi uma redefinição estrutural do capitalismo, promovida pela grande expansão das ferrovias, a construção de navios e a exportação de capitais. A própria demanda interindustrial, fortemente estimulada pela redução de custos gerada pelo progresso técnico, particularmente nos transportes, se encarregava de estimular a acumulação de capital (Hobsbawm, 1977).

Nesta etapa, outros países europeus, como a França, a Alemanha e a Bélgica, se incorporaram ao capitalismo, não mais partindo da indústria têxtil, como foi a história inglesa, mas a partir de grandes investimentos em indústrias de bens de capital e intermediários. Assim também ocorreu com os Estados Unidos e com o Japão. Estas modificações na estrutura produtiva não ocorreriam sem um enorme progresso técnico que inovasse as tecnologias de produção, possibilitasse a exploração e transformação dos recursos naturais necessários e garantisse, pela redução nos custos dos transportes, o acesso às fontes de matéria-prima, energia e aos mercados consumidores. Mas tudo isto implicava enormes investimentos, que exigiam da maioria dos países que se industrializavam um Estado poderoso, amplo acesso aos recursos naturais e um forte capital financeiro, resultado da fusão do capital industrial com o bancário.

Estas transformações estruturais do capitalismo provocaram a unificação econômica do mundo, enormemente facilitada pela revolução tecnológica nos meios de transporte. Não só os fluxos de mercadorias e recursos naturais, mas também os de capital financeiro integravam o mundo. Na verdade, uma integração conflituosa, já que havia uma acirrada concorrência entre os países capitalistas desenvolvidos, que precisavam garantir as 
suas fontes de recursos naturais e mercados para os seus produtos e o seu capital. A expressão política dessa concorrência foi um novo recorte do mundo em áreas de dominação de cada um dos países hegemônicos, um “novo colonialismo” exigido pela nova etapa do capitalismo, chamada de “imperialismo" (Lenin, 1973).

Durante o século XIX, estes países que redefiniram a sua estrutura produtiva praticamente completaram os seus processos de transição demográfica. Alguns governantes, e mesmo alguns economistas, chegaram a se assustar, no início deste período, com a existência de um “excedente demográfico”, principalmente nas cidades que cresciam aceleradamente com a industrialização e apresentavam graves desequilíbrios sociais. O declínio das taxas de fecundidade na segunda metade do século, contudo, contribuiu decisivamente para a desaceleração do crescimento demográfico e para reduzir as preocupações dos teóricos e políticos.

Mas um fator decisivo, foram as migrações internacionais. Estima-se que, entre 1850 e 1914, aproximadamente 30 milhões de pessoas emigraram da Europa para a América, principalmente para os Estados Unidos, Brasil e os países da Bacia do Prata. Foi o maior movimento migratório internacional da história dos povos até aquele momento. Entre 1846 e 1875, 9 milhões de pessoas, quatro vezes a população de Londres, deixaram a Europa. Só das Ihas Britânicas, no período 1851-80, saíram aproximadamente 5,3 milhões de pessoas, sendo que 3,5 milhões para os Estados Unidos, 1 milhão para a Austrália e 800 mil para o Canadá. Calcula-se que, somente na década de 1880, 700 a 800 mil europeus emigraram por ano; para a década seguinte, estima-se algo em torno de 1 a 1,4 milhão por ano (Hobsbawm, 1977).

E não foi só esta migração do centro do capitalismo para a sua periferia, sem dúvida a maior. Os asiáticos, principalmente os chineses, também emigraram para a própria Ásia e para a costa do Pacífico nos Estados Unidos (Hobsbawm, 1977).

Na Europa, o intenso progresso técnico na indústria e, posteriormente, na agricultura, mesmo com a tendência à desaceleração do crescimento vegetativo da população, contribuiu para gerar um excedente demográfico não absorvido pela economia que foi “exportado” para as nações ascendentes. Outros fatores contribuíram para a aceleração das emigrações, como a crise econômica do final do século (1873-90), determinada pela acirrada concorrência intercapitalista. Aliás, as repercussões desta crise nas economias dos países mais avançados não foram tão notáveis a ponto de comprometer a tendência histórica de 
crescimento. Poder-se-ia também falar da instabilidade política. A Europa estava dividida em impérios e alianças, Estados fortes que competiam na conquista de maior espaço para as suas economias e sociedades. O resultado foi a Primeira Grande Guerra Mundial.

Mas tanto a crise econômica quanto a instabilidade política foram apenas aceleradores do movimento das migrações internacionais, que tiveram suas raízes, fundamentalmente, na reestruturação produtiva do capitalismo, que potencializou o excedente demográfico europeu, e na inédita integração econômica do mundo, fortalecida pelo fantástico progresso técnico nos transportes de curta e longa distâncias.

A facilidade de locomoção e comunicação e a integração econômica internacional possibilitaram uma internacionalização do mercado de trabalho. Na própria Europa, a curta distância, e principalmente no circuito Europa-América, a longa distância. Vale a pena voltar a discutir o caso brasileiro, em que as migrações internacionais foram decisivas para a constituição do mercado de trabalho e da própria formação étnica e cultural da nação. No Brasil, os governos do Império e da Primeira República implementaram políticas no sentido de estimular e atrair estes fluxos internacionais. A incapacidade social de se formar um mercado de trabalho capitalista para a economia cafeeira e para as indústrias emergentes só foi superada com a entrada maciça de imigrantes internacionais. Por um lado, havia a incapacidade do plantel de escravos de se reproduzir segundo a demanda da economia cafeeira, já que estava vedado o comércio internacional. Por outro lado, não houve, na proporção necessária, a proletarização de grande parte da população rural, que estava ainda presa a relações de trabalho pré-capitalistas e sujeita a forte controle social e político. Sem a proletarização, as migrações internas ainda eram dificultadas pela inexistência de um sistema de transporte para longas distâncias. Esse lapso histórico entre a ausência de migrações internas e a demanda por força de trabalho foi preenchido pela imigração internacional.

Como já foi mencionado, a deliberada política governamental de atrair imigrantes estrangeiros estava também ligada ao objetivo explícito de "eugenizar“ a força de trabalho no Brasil, marcada pelos séculos de escravidão. Apesar destes objetivos ética e socialmente deploráveis, a miscigenação produzida por essa confluência de povos e culturas distintas trouxe contribuições fundamentais para a formação social brasileira e a sua configuração como nação. 
Gráfico 1- Entradas de imigrantes no Brasil - 1872-1972

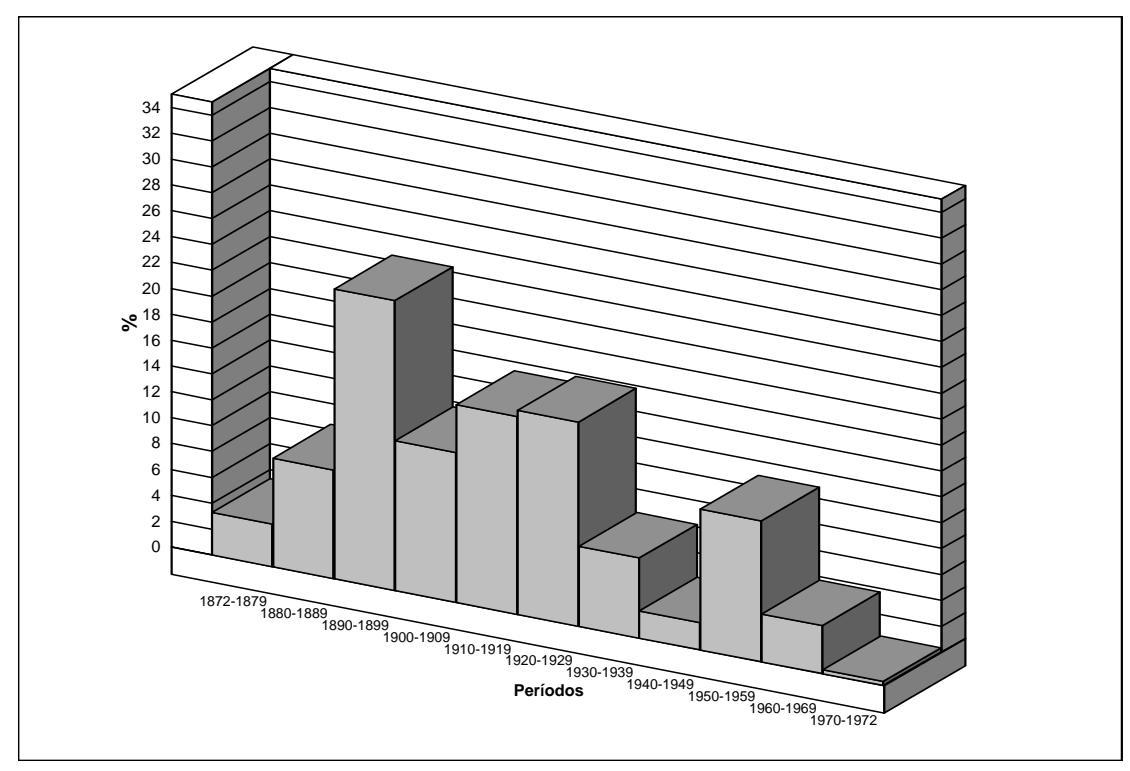

FONTE: Levy (1974).

O período no qual se deu a maior entrada de imigrantes no Brasil foi entre 1890 e 1929, com destaque para o decênio 1890-99, quando aqui chegaram quase 1,2 milhão de imigrantes. Nestes 40 anos os fluxos foram praticamente comandados pelas políticas de subsídio à imigração e pelas necessidades da economia cafeeira em expansão para o Oeste Paulista. Os italianos eram nitidamente predominantes, mas os portugueses e espanhóis também se destacavam.

No início deste século, até 1929, cresce a imigração portuguesa e de outras nacionalidades, como alemães, poloneses, russos, judeus, romenos, e o número de italianos e espanhóis começa a decair acentuadamente. A grande novidade é a intensificação do fluxo de japoneses no período entre as duas Grandes Guerras.

Até a década de 30, o capitalismo se expande puxado pelo notável desempenho da economia americana. Os Estados Unidos, além de desenvolverem rapidamente o seu setor de bens de capital e intermediários, também implementaram uma indústria de bens de consumo duráveis cuja grande vitrine era a indústria automobilística. A partir da crise de 1929, e com a 
grande depressão dos anos 30, o capitalismo internacional entra numa fase conturbada. A emergência e expansão da experiência soviética, de um lado, e a crise econômica, de outro, contribuem para um “enrigecimento de fronteiras” e, em alguns países, ondas nacionalistas acabam por desembocar no fascismo.

Nesse contexto, as emigrações européias tenderam a se reduzir drasticamente. As crises econômica e política esmoreciam os fluxos migratórios. A perspectiva de guerra tornava o cenário internacional ameaçador e pouco propício a grandes movimentos internacionais de populações. Portanto, a tendência era que as migrações se restringissem às do tipo étnicas e de refugiados. Considerando, também, que o crescimento vegetativo da população era extremamente baixo, não havia a necessidade de exportar nenhum "excedente demográfico”.

Os países tradicionalmente de destino migratório, depois de 1930, também não tinham a mesma capacidade de atração. Os Estados Unidos, enfrentando as adversidades da Grande Depressão, com altíssimas taxas de desemprego, já não eram o mesmo paraíso migratório de antes. O Brasil, como outros países da periferia capitalista, ampliou a sua industrialização após a Revolução de 1930, começando, então, a substituir as importações de bens de consumo duráveis e intermediários. Entretanto, as necessidades de força de trabalho eram mais facilmente supridas pelas próprias migrações internas, que começaram a se intensificar na década de 40.

Após a Segunda Grande Guerra há uma expansão inusitada do capitalismo, tanto nos Estados Unidos, quanto na Europa e Japão, depois de se recuperarem dos efeitos do conflito. O mundo pós-guerra foi redesenhado politicamente segundo as duas potências hegemônicas, os Estados Unidos e a então União Soviética. Alguns países periféricos segundo um novo padrão de divisão internacional do trabalho, entre eles o Brasil, assumem uma nova forma de inserção dentro do capitalismo mundial, usufruindo das possibilidades de crescimento e da liquidez do capital financeiro disponível. Na década de 50, a economia brasileira irá se expandir bastante e receber um fluxo maior de imigrantes advindos das regiões mais atrasadas da Europa, com a predominância de portugueses.

Foram justamente os países periféricos, antes receptores de imigrantes, que apresentaram, depois da Segunda Grande Guerra, as mais altas taxas de crescimento demográfico. Mas o próprio crescimento econômico destes países, as exigências do mercado 
de trabalho interno e a redução enorme dos custos de transportes fizeram com que a dimensão assumida pelas migrações internas tornasse as internacionais praticamente irrelevantes.

Os fluxos migratórios internacionais da periferia para o centro foram bem localizados e, geralmente, de curta distância. Para os Estados Unidos se destacaram as migrações do México, país fronteiriço. Os mexicanos contribuíram para potencializar a população de língua espanhola residente na América do Norte, hoje estimada em mais de 20 milhões. Para a Europa, principalmente para a Inglaterra, Alemanha, França e Suíça, vieram muitos imigrantes de Portugal, Espanha, Grécia, Turquia, Finlândia, Irlanda e da antiga Iugoslávia. Estima-se que, em 1975, 10\% da força de trabalho da Europa Ocidental eram constituídas de imigrantes (Sales, 1991).

Em ambos os casos, Estados Unidos e Europa, a grande expansão da economia no pós-guerra gerou uma “dependência do trabalhador estrangeiro”, seja para trabalhos temporários, de longo prazo ou permanentes. Os imigrantes eram necessários porque a população economicamente ativa não crescia o suficiente para atender todas as necessidades do mercado de trabalho, dado que o crescimento vegetativo era bastante baixo.

Aos imigrantes era reservado, prioritariamente, um "espaço secundário do mercado de trabalho”, onde prevaleciam as ocupações menos valorizadas por uma população coberta por eficientes programas de seguridade social e por poderosas organizações sindicais. O “espaço principal do mercado de trabalho” convivia bem com o secundário e, algumas vezes, dele se nutria, mantendo no imigrante a expectativa de mobilidade no mercado de trabalho e de uma maior integração social no país de destino. De qualquer maneira, a imigração era necessária para a reprodução da economia e da sociedade dos países mais avançados da Europa e da América Norte.

Além dessa migração tipicamente comandada pelo mercado de trabalho internacionalizado, existiam outros fluxos, alguns de longa distância, entre as colônias e os antigos países colonizadores. Os fluxos da Índia e Paquistão para a Inglaterra ou do Norte da África para a França seriam alguns exemplos. Os fluxos étnicos e de refugiados também foram importantes, principalmente do Leste Europeu em direção à própria Europa Ocidental, Oriente Médio e Estados Unidos. Alguns cálculos mostram que, entre 1950 e 1993, 14.160.000 emigrantes saíram da antiga Alemanha Oriental, da ex-Iugoslávia, da Polônia e da 
antiga União Soviética em direção, fundamentalmente, à ex-Alemanha Ocidental , Israel e Estados Unidos (Heinz e Munz, 1994).

Depois da década de 70, o cenário no qual se realizavam as migrações internacionais se modificou substancialmente. Os fluxos dos países em desenvolvimento em direção aos países mais desenvolvidos se acentuaram bastante. Segundo os dados do Fundo das Nações Unidas para a População - FNUAP (1993), só entre 1980 e 1992 entraram legalmente na Europa Ocidental 15 milhões de imigrantes. Nos países da Comunidade Européia, em 1990, residiam 13 milhões de estrangeiros, sem incluir os naturalizados. Oito milhões de imigrantes vieram de fora da CEE, sendo 4 milhões procedentes do Norte da África, Turquia e Iugoslávia.

O levantamento do FNUAP citou mais alguns dados importantes:

A antiga Alemanha Ocidental, em 1980, tinha 4,5 milhões de imigrantes, número que passou para 5,2 milhões em 1990, cerca de 8,4\% da população total. Os maiores fluxos migratórios eram de turcos (1,7 milhão), iugoslavos (652 mil) e poloneses ( 241 mil).

Na França, em 1990, 6,4\% da população eram de imigrantes. Isto sem considerar mais de 1 milhão de estrangeiros nacionalizados e 500 mil cidadãos franceses das províncias ultramarinas e territórios na África, Caribe e Pacífico.

O Reino Unido, em 1990, tinha 1,9 milhão de imigrantes, isto é, 3,3\% da população total. A sua população de minorias étnicas, oriunda principalmente do Caribe e do Sul da Ásia, era 4,7\% da população total. A estimativa da população total de origem imigrante chegava a 4,5 milhões, ou seja, 8,7\% da população total.

Nos Estados Unidos entraram, durante a década de 1980, 7.338 .000 migrantes legais, oriundos principalmente de países em desenvolvimento. Considerando a enorme entrada de imigrantes ilegais, estima-se para a década passada um fluxo de imigrantes de cerca de 10 milhões.

O Japão é outro país de grande atração migratória para as populações de países em desenvolvimento como Bangladesh, Paquistão e Irã. Apesar das restrições impostas para a obtenção de vistos no início da década de 80, entre 1989 e 1992 o número de estrangeiros que permaneceram no país um tempo superior ao permitido pelo visto aumentou de 20.500 
para 280 mil. O Brasil tem sido um grande fornecedor de imigrantes para o Japão, os chamados "dekasseguis“, homens e mulheres de origem familiar japonesa que vão ao Japão temporariamente para exercerem trabalhos não-qualificados (Rossini, 1992).

Outros países como a Austrália, o Canadá, Cingapura, os grandes produtores de petróleo asiáticos também têm se constituído em países de atração migratória. A República da Coréia, que tem $11 \%$ de sua população residindo no exterior, tem estimulado a imigração internacional para suprir a escassez interna de mão-de-obra.

Gráfico 2 - Porcentagem de imigrantes na força de trabalho

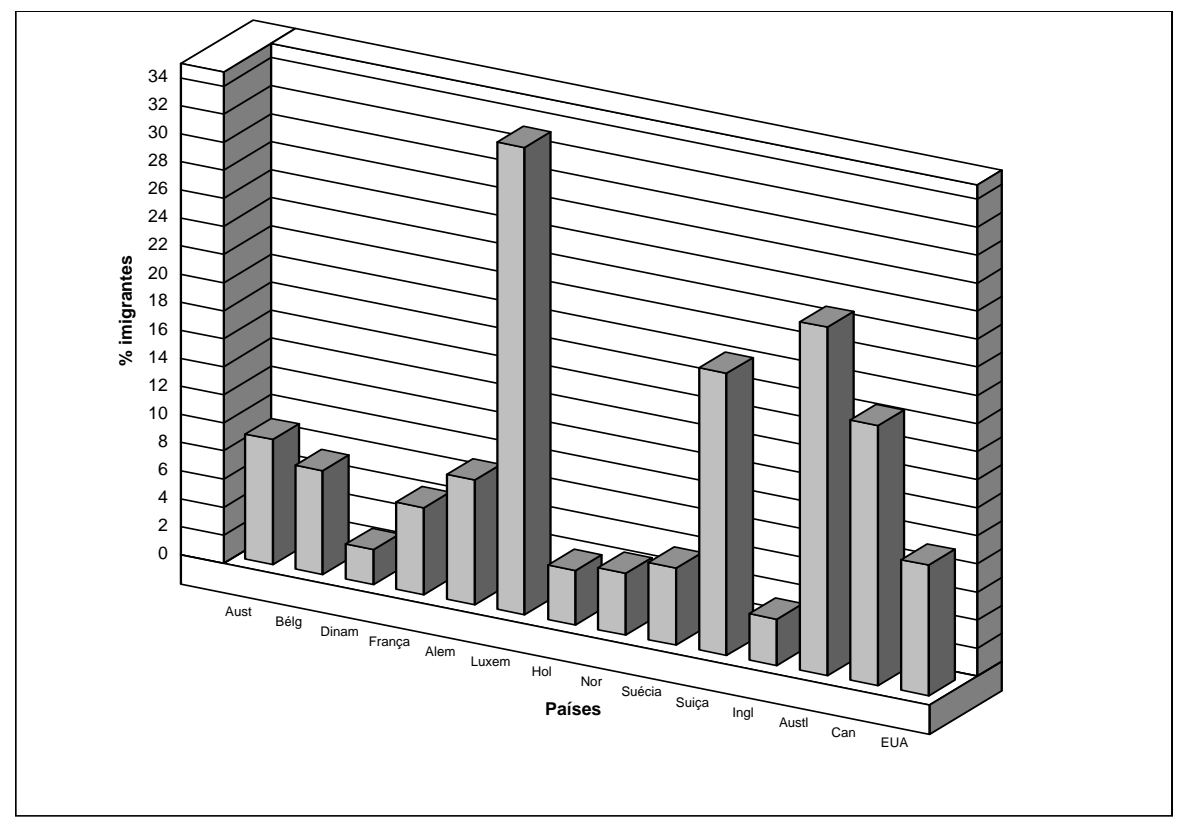

FONTE: The OECD Observer, n. 192, fev.-mar., 1995

Os dados da OECD para 1991 confirmam a presença importante dos imigrantes na força de trabalho dos países mais desenvolvidos. Áustria, Alemanha, Luxemburgo e Suíça se destacam na Europa. O Canadá e os Estados Unidos também apresentam uma grande presença de mão-de-obra imigrante, ao passo que na Austrália esta é quase $25 \%$ da força de trabalho (The OECD Observer, n. 192, fev.-mar., 1995).

Um outro excelente exemplo tem sido o Brasil, que sempre foi um lugar de atração migratória e passou a ser, também, exportador de força de trabalho para os Estados Unidos, Europa e Japão. 
Se por um lado houve esta intensificação das migrações das populações dos países em desenvolvimento em direção aos mais desenvolvidos, por outro, o capitalismo tem passado por profundas transformações na sua estrutura produtiva. Além disso, deve ser mencionado o “conflito demográfico” causado pelo envelhecimento da população, o que tem pressionado a capacidade de financiamento do Welfare State, pelo estreitamento gradativo de sua base, ou seja, pela diminuição da relação entre a população economicamente ativa e a não ativa (apesar de a PEA ainda estar sendo afetada pelo "babyboom” do pós-guerra). Os Estados têm passado por uma crise fiscal que tem se desdobrado em restrições às políticas de seguridade social e em estímulos a um mercado de trabalho mais competitivo.

A reestruturação produtiva, ou a chamada Terceira Revolução Industrial, tem gerado transformações rápidas e profundas nos países mais desenvolvidos. Estas têm sido rápidas porque a acirrada concorrência entre Europa, Estados Unidos e Japão tem exigido ajustes macroeconômicos de curto prazo, ou seja, na medida exata das exigências de uma economia internacional globalizada, em que cada país tem os seus mercados nacionais abertos e, portanto, sujeitos aos padrões internacionais de eficiência e competitividade.

Estas rápidas transformações da estrutura produtiva capitalista têm incorporado novos padrões de utilização de insumos tradicionais, como o aço e o cobre, cada vez mais substituídos por novos materiais, com o claro propósito de aumentar o valor agregado e superar as dificuldades com os mercados de recursos naturais e energéticos. Com o mesmo objetivo de aumentar a eficiência, os processos produtivos estão cada vez mais automatizados e robotizados, o que, junto com a flexibilização tecnológica, isto é, "a utilização de equipamentos de propósitos múltiplos e versáteis", têm provocado mudanças profundas no mercado de trabalho (Cano, 1993). Acrescente-se que a flexibilização só se viabiliza com uma nova organização do trabalho que gradativamente vai superando o antigo “fordismo”.

Apesar da criação de novos cargos, requeridos pelos novos processos tecnológicos e pelas novas formas de organização do trabalho, tem havido uma enorme redução nas necessidades de mão-de-obra. Mais ainda: os mercados de trabalho estão mais seletivos, exigindo maior treinamento e reciclagem. Como conseqüência, verifica-se um aumento fantástico das taxas de desemprego, que em alguns países desenvolvidos já chegam a mais de 20\%. Tem havido, também, uma grande rotatividade da mão-de-obra, a substituição de empregos pelo "trabalho domiciliar" e o aumento da substituição do trabalho masculino pelo feminino em setores como a construção civil. Na década de 80, o trabalho feminino na 
construção civil cresceu 23\% na Itália, Inglaterra e Japão, 48\% nos Estados Unidos e 75\% na Espanha (Cano, 1993).

O mercado de trabalho está cada vez mais seletivo e competitivo, gerando um "excedente estrutural de força de trabalho" que tem avançado inclusive sobre os "espaços secundários do mercado de trabalho", tradicional nicho dos imigrantes. A crise do Welfare State e a existência deste excedente estão na raiz do ambiente cada vez mais adverso para os imigrantes de outros países, outrora tão "bem-vindos" e necessários.

A globalização e acelerada interdependência têm levado à formação de blocos de países como o NAFTA, a CEE e o Mercosul. Para facilitar a sobrevivência sob condições de alta competitividade, os países têm se agrupado, diluindo alguns limites do Estado nacional. Estados passam a dividir com outros Estados a formulação de alguns parâmetros básicos da política econômica e monetária. A contrapartida tem sido o ressurgimento de movimentos nacionalistas e étnicos, como se o reforço da identidade nacional pudesse compensar a internacionalização de algumas funções do Estado nacional. Para esta "xenofobia" tem contribuído, após a derrocada das experiências socialistas, a tendência à substituição de fronteiras ideológicas por fronteiras étnicas.

Mercados de trabalho competitivos e seletivos, nacionalismo e preconceitos étnicos redefiniram o significado das migrações internacionais para os países desenvolvidos. Se até a década de 70 os migrantes eram necessários economicamente e aceitos socialmente, nos anos 80 passaram a ser competitivos com os nacionais no mercado de trabalho e objeto de discriminação social e legal.

Para tornar mais complexo o cenário atual das migrações internacionais, obsevese que, ao contrário do que ocorreu na Segunda Revolução Industrial, os fluxos migratórios que se intensificam são no sentido da periferia para o centro do capitalismo, ou dos países em desenvolvimento para os mais desenvolvidos. Mesmo porque, as condições sociais, econômicas e demográficas dos países mais pobres estão longe de exercerem a mesma atração de um século atrás.

Os países mais pobres, como o Brasil, viveram na década de 80 tentativas malsucedidas de ajuste econômico e financeiro, visando à nova realidade do capitalismo internacional e à necessidade de saldarem os compromissos com os pagamentos das dívidas 
externas. O resultado foi uma década de crise econômica com uma profunda dimensão social, em que as taxas de desemprego se aproximaram dos 15\% e a miséria se generalizou para $20 \%$ da população.

A globalização da economia também tem imposto aos países em desenvolvimento, para que se tornem competitivos internacionalmente, a "importação da reestruturação produtiva" que, somada a um crescimento demográfico bem acima daquele dos países do Primeiro Mundo, tem produzido mercados de trabalho seletivos e competitivos, principalmente nos setores mais modernos da economia, altamente oligopolizados. É claro que a queda da fecundidade e o declínio generalizado nas taxas de crescimento populacional devem ter ajudado a reduzir a pressão populacional sobre os mercados de trabalho. Entretanto, a fantástica redução das taxas de crescimento das grandes regiões metropolitanas de países como o Brasil sinaliza também para outro fenômeno: a redução das migrações internas, principalmente as inter-regionais. Os grandes centros urbanos deixaram de ter o enorme poder de atração que tiveram em décadas anteriores, não só pela crise econômica, expressa no maior fechamento dos mercados de trabalho, mas pela dimensão social que ela encerra. E aqui vale a pena chamar a atenção para um fenômeno recente, fundamental na sociedade brasileira: o descolamento da mobilidade espacial da mobilidade social.

Em períodos de expansão econômica e mercados de trabalho mais abertos, o processo migratório interno significava a possibilidade de o indivíduo se mover na escala social mediante uma bem-sucedida mobilidade ocupacional e uma conseqüente melhoria do seu padrão de renda no lugar de destino. A verdade, porém, é que o processo migratório era seletivo. Uma grande parte dos migrantes não conseguia sucesso nesta mobilidade, só restando a eles o retorno às origens ou o itinerário de milhões de brasileiros: pular de cidade em cidade ou de região em região, como nômades sociais.

O importante é que essas possibilidades de mobilidade social, mesmo não sendo para todos os emigrantes, estão tendendo a se esgotar. Os empregos em mercados de trabalho "menos nobres” ou em "espaços secundários", como a construção civil, ou mesmo no mercado informal, se tornaram muito mais competitivos. Simultaneamente, os mercados de trabalho dos setores mais modernos da economia se tornaram mais fechados e oligopolizados, fruto da aliança das corporações empresariais com os trabalhadores com o objetivo de se manterem os lucros e os salários reais. Os pré-requisitos para a entrada nestes mercados também ficaram mais rígidos quanto às necessidades de formação profissional e "on the job 
training”. O resultado é que se tornou impossível, para a grande maioria dos migrantes, associar a sua mobilidade espacial a uma maior mobilidade ocupacional e social. Não foi por outra razão que a migração para as regiões antes de grande atração migratória, como as regiões metropolitanas, reduziu-se enormemente. As crises econômica e social certamente contribuíram para agravar esta situação, mas mesmo aqueles setores mais modernos que conseguiram, recentemente, recuperar suas taxas de crescimento não recuperaram na mesma proporção as suas taxas de absorção de mão-de-obra. E o motivo é que o crescimento destes setores dentro do padrão internacional da “reestruturação produtiva” tem economizado largamente a mão-de-obra.

Para muitos, aqueles com um padrão educacional mínimo, a possibilidade de mobilidade social ficou restrita a uma alternativa praticamente inédita em décadas anteriores: a emigração para os Estados Unidos, Europa ou Japão. Evidentemente, esta mobilidade não acontece nos países de destino. Lá as condições, como foi observado, são altamente adversas e a inserção do imigrante se dá na periferia do mercado de trabalho ou no seu "espaço secundário", onde, atualmente, muitas vezes têm de competir com os nacionais. Mas, mesmo assim, com toda a adversidade, competitividade e discriminação, tem sido possível para muitos imigrantes construir uma reserva financeira que, enviada para o Brasil, permite a aquisição de bens ou investimentos que garantem, fora da trajetória ocupacional, uma elevação do padrão de vida e do consumo.

Se, na época da Segunda Revolução Industrial, a intensificação das migrações foi facilitada pelo progresso técnico nos transportes, agora um outro fenômeno torna-se decisivo. Aliada à globalização da economia emerge uma verdadeira "sociedade global”, onde os processos sociais que antes se limitavam às fronteiras de cada Estado-nação hoje tendem a se internacionalizar. Os modernos sistemas de telecomunicações fazem com que as informações circulem numa grande velocidade e cheguem a milhões de domicílios em diferentes países. Estas informações trazem consigo normas e valores que se internacionalizam, possibilitando a diferentes povos a redefinição de padrões e aspirações de comportamento e, portanto, a construção de um imaginário sobre a realidade do seu e de outros países. Deste imaginário, fruto da internacionalização de processos sociais, é que cada migrante internacional potencial cria a sua "ilusão migratória", sem a qual ninguém migra a longa distância, principalmente entre países. É claro que existe também uma "racionalidade" baseada num cálculo de custos e benefícios da migração internacional - que também está condicionada por processos sociais 
internacionalizados -, mas a expectativa de sucesso na migração vem alimentada por uma ilusão sobre as condições do país de destino que ultrapassa a realidade. E, sem a "ilusão migratória”, a motivação para emigrar não acentua suficientemente os benefícios econômicos, sociais e psicológicos da migração, sem os quais os custos se transformam em obstáculos intransponíveis.

As informações que circulam pela mídia são reforçadas pelas "redes sociais de imigrantes”. Esta é uma característica fundamental das migrações a longa distância e, sem dúvida, das internacionais. Ninguém migra isoladamente. O processo migratório tende a ser coletivo, funcionando como uma bola de neve. Os que migram estabelecem entre si uma "rede” de informações e apoio visando não só informar sobre as condições do país de destino, como facilitar a adaptação do imigrante. Estas "redes sociais de cooperação" são fundamentais e, no limite, tendem a reforçar, nos países de destino, verdadeiros guetos de imigrantes onde, interagindo entre si, eles se defendem no difícil processo de integração na sociedade e economia dos países mais avançados.

A integração social do imigrante é uma questão decisiva. Ela é praticamente impossível para a grande maioria, devido não só à competitividade no mercado e à quase total impossibilidade de se deslocar para o espaço principal do mercado de trabalho, mas, fundamentalmente, devido às diferenças sociais e culturais e aos preconceitos. Mais recentemente, tem sido comum em muitos países as restrições legais à integração dos imigrantes. Estes tendem, então, a viver no país de destino uma “cultura da passagem”: estão em outro país, têm dificuldades enormes de se integrarem socialmente e, como defesa social, vivem em guetos onde recriam os padrões de vida dos países de origem. Muitas vezes não aprendem a língua nem regularizam juridicamente sua situação no país. A tendência tem sido os imigrantes reforçarem as redes sociais de cooperação formando verdadeiras ilhas da “cultura da passagem”.

Esta cultura e os guetos ajudam o migrante a conviver com o conflito entre as necessidades de gerar uma reserva financeira, com todos os custos sociais e psicológicos que isto implica, e a auto-imagem fundada nos seus valores de trabalhador com um mínimo de formação educacional, geralmente de classe média, no país de origem. Há uma espécie de compensação entre os ganhos econômicos e financeiros e as perdas no status e prestígio social. 
A migração da periferia para os países mais avançados, que foi o objeto principal deste ensaio, coexiste com um outro tipo que merece ser mencionado: a migração em regiões de fronteira entre países mais pobres em desenvolvimento. É o caso de alguns países latinoamericanos, cujos mercados de trabalho regionais, assim como os mercados de terras, tendem a se internacionalizar.

O Brasil, novamente, é um bom exemplo. Inserido no Mercosul e fazendo fronteiras com outros países latino-americanos, ele também tem se integrado com estes países mediante fluxos de população. Bolivianos, chilenos, peruanos e paraguaios têm imigrado para o Brasil em grandes quantidades. Interessante é que tende a se reproduzir aqui o que ocorre com os brasileiros que emigram para os países mais avançados: geralmente eles se inserem no "espaço secundário do mercado de trabalho", em atividades periféricas não regulamentadas pela legislação trabalhista. O caso dos bolivianos em São Paulo é ilustrador (Galleti, 1995). Eles trabalham nas indústrias de confecção, hoje totalmente controladas pelos imigrantes coreanos, onde não têm nenhuma proteção da legislação trabalhista. A aceitação desta situação pelos bolivianos se justifica, na maioria das vezes, pela sua própria condição ilegal no Brasil.

Além da internacionalização do mercado de trabalho entre países vizinhos, o mercado de terras também é decisivo para as migrações. A grande emigração de brasileiros para o Paraguai foi predominantemente determinada por projetos de colonização e pelas diferenças no preço da terra, bem mais baixo em regiões paraguaias do que nos estados do sul do Brasil. Ou seja, a internacionalização de outros mercados de fatores de produção, como a terra, também é decisiva para as migrações entre países vizinhos (Reydon e Platz, 1995).

As regiões de livre comércio, como o Mercosul, tendem a levar ao limite a internacionalização dos mercados de fatores de produção, já que as restrições alfandegárias são fortemente reduzidas. Porém, a integração mercantil não significa a diluição dos limites do Estado-nação, e muito menos das suas heterogeneidades. As diferenças quanto à legislação trabalhista e às políticas salariais ou de terras, que são decisivas para as migrações internacionais, dificilmente serão homogeneizadas. Portanto, os fluxos de população continuarão existindo, sinalizados pelos desequilíbrios ou diferenças entre os vários países.

Para finalizar, vale a pena mencionar que as migrações internacionais, seja a curta ou a longa distâncias, fazem parte do cenário internacional hoje, assim como o fizeram há 
cem anos atrás. Só que no final do século passado e princípio deste as migrações tendiam a ser permanentes e os migrantes se integravam econômica e socialmente nos países de destino. Eram, sem dúvida, fluxos socialmente desiguais que se inseriam desigualmente nas sociedades. Mas foi a partir da convivência destes diferentes povos que muitas nações se fizeram. Atualmente, a realidade migratória é distinta: fruto da internacionalização do mercado de trabalho e da profunda desigualdade entre as nações, a maioria das migrações tende a ser cada vez mais temporária e os migrantes, meros trabalhadores que circulam internacionalmente. Em vez de serem convidados a “fazer a América”, como se dizia há um século, hoje eles são como atores convidados a desempenhar um papel secundário no mercado de trabalho, por um tempo determinado. E, logo após, são convidados a se “desfazer” da América , da Europa ou do Japão.

\subsubsection{Migração e Tráfico de Seres Humanos}

Considerando este problema, como mundial, o Site Imigrantes (disponível em: http://imigrantes.no.sapo.pt/page4.html, 2003) contextualiza bem a questão dos povos que decidem migrar para outros países, demonstrando as precárias condições em que eles costumam ser recebidos e os riscos corridos. Não são raros os casos de escravidão, prostituição, etc. Neste sentido, a Organização Mundial das Migrações (OIM) calculava, em 2001, que existiam em todo o mundo cerca de 30 milhões de imigrantes em situação ilegal. A única certeza que se tem é que o seu número não pára de aumentar. Sinal mais que evidente que os problemas que provocam esta migração de último recurso persistem.

\subsubsection{Estatísticas da Emigração Mundial}

Em todo o mundo existem 175 milhões de emigrantes (3\% da população mundial). Os países com mais emigrantes são os EUA (35 milhões), a Federação Russa (13,3 milhões), seguidos da Alemanha (7,3 m.), Ucrânia (6,9 m.), França e Índia (6,3 m.), Canadá (5,8m.), Arábia Saudita (5,3 m.), Austrália (4,7 m.). 
A Europa é o continente com maior número de emigrantes (56,1 milhões), seguido da Ásia (50 milhões) e da América do Norte (41 milhões). As remessas dos emigrantes para os seus países de origem são assim escalonadas: Em 2000, no primeiro lugar surgiam os indianos (enviaram cerca de 11,5 milhares de milhões de euros), seguidos dos mexicanos (6,5 milhares de milhões), turcos $(4,5)$, egípcios $(3,7)$, espanhóis $(3,4)$ e em sexto lugar surgiam os emigrantes portugueses que enviaram para país, neste ano, cerca de 3,1 milhares de milhões de euros.

\subsubsection{Tráfico de Seres Humanos}

Um dos negócios mais lucrativos a nível mundial é o do tráfico de seres humanos. Ele alimenta as redes de prostituição, mas também da escravatura e da guerra.

Como no passado, o trabalho escravo e as redes de prostituição constituem neste momento, um dos negócios mais lucrativos em todo o mundo. Os números são os mais diversos, uma certa é certa: o tráfico de seres humanos continua próspero em todo o mundo.

\subsubsection{Trabalho escravo}

Milhões imigrantes ou refugiados acabam todos os anos nas garras de organizações mafiosas que os escravizam. O esquema repete-se em todo o lado. Quando os imigrantes ou os refugiados chegam aos países de destino, as máfias locais começam por lhes ficar com a documentação. Depois obrigam-nos a trabalhar em condições miseráveis e ficamlhes com grande parte do que recebem. O pretexto é que devem pagar a dívida da viagem, o alojamento, o suborno das autoridades locais, etc. Em pouco tempo estes imigrantes percebem que nunca chegarão a pagar a dívida que supostamente contraíram no início do processo e que não pára de aumentar. Isolados, desconhecendo a língua do país de acolhimento, sem documentação ou em situação ilegal tornam-se presa fácil de máfias que operam a uma escala cada vez mais global.

Os casos repetem-se em todos o continentes e países. Portugal é referenciado como um dos países onde as máfias traficam pessoas oriundas da Ex-União Soviética 
(Ucrânia, Moldávia, Rússia, Roménia, Lituania, Bielorrúsia), mas também do Brasil. Serve igualmente de plataforma para o tráfico para outros países, como a Grã-Bretanha.

Na Inglaterra, a imprensa tem denunciou, em Maio de 2003, a existência de milhares de emigrantes portugueses escravizados por máfias locais.

\subsubsection{Tráfico de Crianças}

A OIT afirma que atualmente cerca de 8,4 milhões de crianças são diretamente exploradas por redes que se dedicam à prostituição e escravatura (Dados de Junho de 2003). A utilização de crianças em conflitos armados, continua a ser uma prática muito freqüente, sobretudo em África. Na Serra Leoa, por exemplo, são raptadas e obrigadas a combater como soldados em grupos rebeldes. Alguns grupos armados chegam inclusive a marcá-las para que não possam fugir. Muitas são igualmente usadas para detectar e limpar minas. Raparigas com menos de 10 anos, servem de companhia a soldados.

É impressionante a extensão das redes de trafico de crianças para a prostituição. Muitas destas crianças são mortas em práticas sexuais, nomeadamente nos países ditos mais desenvolvidos.

Em Portugal, em 2003, o país acordou para um pesadelo, ao descobrir que numa instituição pública de crianças - Casa Pia - as suas crianças alimentavam uma rede de pedófilos. Esta rede atuava desde os anos 70 na mais completa impunidade.

Em todo o mundo cerca de 246 milhões de crianças (73 milhões com menos de 10 anos) são usadas em todo o tipo de trabalhos, nomeadamente para a produção de produtos para grandes marcas internacionais (Dados de OIT, Junho de 2003).

\subsubsection{Tráfico de Mulheres}


Muitas mulheres são raptadas, outras são simplesmente iludidas por promessa de uma vida melhor. O fim para milhões delas é conhecido: a prostituição ou a escravatura. As páginas da imprensa internacional enchem-se destes casos:

Mulheres do leste da Europa após serem violadas e drogadas são forçadas a prostituírem-se na Itália, Alemanha e outros países. Mulheres do sudoeste asiático que trabalham como domésticas no Golfo Pérsico acabam por ser violadas pelos seus patrões.

\subsubsection{A Imigração e as Suas Causas}

As causas da imigração são quase sempre as mesmas: a fuga à pobreza, desemprego, destruição do meio ambiente, guerra, violência, perseguição política ou religiosa. Neste campo, não é fácil distinguir por vezes, a fronteira entre o imigrante e o refugiado. Ambos fogem a uma situação intolerável que os obriga a deixar a terra onde nasceram. Imigra-se também para aproveitar oportunidades de emprego que se oferecem em alguns países que carecem de mão-de-obra.

A imigração legal, apesar do que se afirma, constitui o principal meio de migração das pessoas. $\mathrm{O}$ envelhecimento das populações dos países economicamente mais desenvolvidos, implica um contínuo recurso à mão-de-obra estrangeira. O mundo conta atualmente, segundo a OIM, com cerca de 150 milhões de imigrantes.

A imigração ilegal, tem vindo contudo a crescer, constituindo atualmente um próspero negócio para as redes de tráfico de seres humanos que operam em todo o mundo.

A imigração não é um mal, muito pelo contrário, inúmeros exemplos históricos mostram que a mesma tem constituído um poderoso meio para o desenvolvimento cultural, social e econômicos da humanidade.

Urge todavia combater as causas da imigração que se apresenta como a única alternativa para a sobrevivência das pessoas, e que é objeto de exploração de redes de tráfico de seres humanos. Para isso impõe-se, nesta aldeia global, entre outras as seguintes medidas: adoção de uma diplomacia preventiva; um maior empenho na ajuda aos países do hemisfério sul; sanções duríssimas para com os regimes que não respeitem os direitos humanos. 


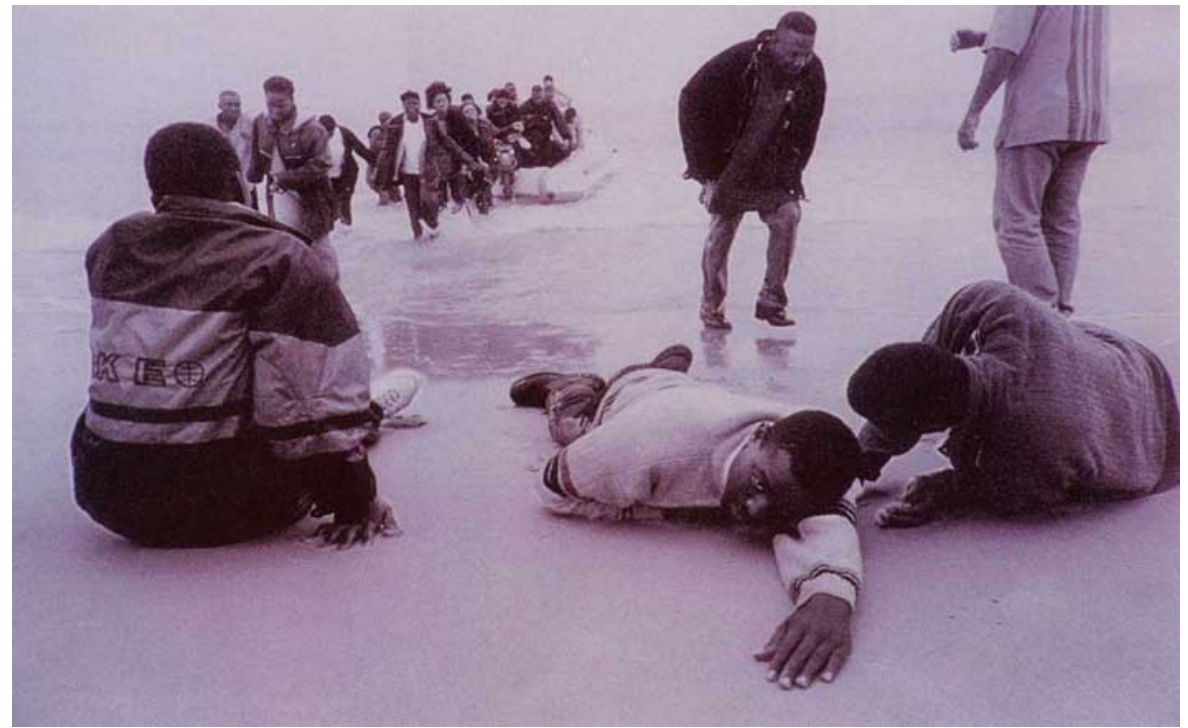

Fotografia de Matias Costa - Imigrantes clandestinos africanos chegam às costas de Espanha. Um drama que se repete diariamente e que provoca desde finais dos anos noventa um número indeterminado de mortes.

\subsubsection{Os Fluxos Migratórios de Criciúma}

Gláucia de Oliveira Assis (2002), faz uma análise muito rica sobre os casos de migração da Cidade de Criciúma, que fica no Estado de Santa Catarina. Esta cidade já é tradicionalmente reconhecida pelos seus excessivos casos de fluxos migratórios, principalmente para os Estados Unidos. Neste sentido, apresenta-se uma adaç

Iracema voou para a América Leva roupa de lã e anda lépida Vê um filme de quando em vez. Não domina o idioma inglês Lava chão numa casa de chá. (....) Chico Buarque

No final dos anos 90 milhares de brasileiros voaram para “Fazer América”. Esse novo movimento da população brasileira que na década de 90 consolidou uma migração para os Estados Unidos, a Europa e o Japão, marca uma inversão da auto-imagem do país como uma nação de imigrantes. Conforme demonstraram vários estudos (Sales 1992 e 1999a, Assis 2002 e 1999, Martes 1999, Margolis 1994), o fluxo de brasileiros para o exterior tornou-se uma questão relevante, na medida em que, o que era um movimento esporádico para o estrangeiro nos anos 70 transformou-se num fluxo migratório demograficamente significativo. 
É importante destacar ainda que ocorreu no mesmo período uma nova corrente migratória para o Brasil. Esses dois movimentos de e/imigração colocaram o Brasil, no final do séc. XX, nos novos fluxos internacionais de mão-de-obra.

Nos versos da música de Chico há ainda um sugestivo tema para esse artigo. Iracema, emigrante brasileira, é uma mulher e, participa como outros milhares de emigrantes brasileiros do projeto de tentar a vida na “América”. Essa característica, não apenas da migração de brasileiros, mas da migração internacional - aponta para o aumento da participação feminina nos mesmos. Segundo Zlotnik (1998) o número de mulheres migrantes no mundo aumentou 63\% - de 35 milhões par 57 milhões - entre 1965 e 1990, um crescimento 8\% maior que os imigrantes masculinos. Nos Estados Unidos, 53,3\% dos novos imigrantes eram mulheres, em 1998. A maior visibilidade das mulheres nas migrações internacionais recentes contribuiu para problematizar as visões cristalizadas sobre a inserção de homens e mulheres migrantes nesse processo.

No caso da recente emigração de brasileiros para os Estados Unidos, as pesquisas começaram seguindo o percurso dos próprios fluxos migratórios. Ao longo dos anos 90, conforme demonstram os trabalhos de Martes (2000), Sales (1999a), Reis e Sales (1999), o fluxo de brasileiros para os Estados Unidos manteve-se contínuo, ao mesmo tempo em que se diversificava a população, complexificando as características da população migrante, bem como revelando outros pontos de partida para a emigração. Dentre esses trabalhos, alguns apontaram para a inserção diferenciada de homens e mulheres ao longo do processo migratório. Martes (1999) descreveu o nicho criado pelas mulheres brasileiras no setor da faxina doméstica em Boston. Debiaggi (2002) analisou o impacto nas relações entre homens e mulheres quando essas passam a ganhar tanto ou mais que os homens. O trabalho de Fusco (1999: 2000), embora não trabalhe com o recorte de gênero para analisar as relações entre homens e mulheres, discute os diferenciais por sexo na migração de valadarenses para os Estados Unidos, reunindo dados que demonstram que as mulheres participam de forma ativa da migração de longa distância, integrando redes de migração.

2.6.3.1 Partindo de Criciúma: tecendo redes familiares e de gênero rumo aos estados unidos. 
A região que hoje compreende a cidade de Criciúma está localizada ao sul do estado de Santa Catarina e distante de Florianópolis 190 Km (via BR 101). No final do séc. XIX, a região sul do Estado de Santa Catarina constituiu-se num encontro de etnias das quais a italiana representa uma parcela significativa (Arns 1985, Baldin 1987, Nascimento 1993), que ali se instalaram como aspiração do governo ao projeto de colonização de terras do interior do país com mão-de-obra européia e não mais escrava.

É importante observar que os relatos sobre a história da cidade enfatizam a imagem heróica do pioneiro. Os relatos enfatizam como os imigrantes deixaram a Itália, um país em crise após a unificação, e migraram para o Brasil em busca de terra e melhores condições de vida. O sucesso migratório é apresentado como resultado da coragem e do empenho dos imigrantes, pois eram colonos sem terra na Itália, tornaram-se proprietários de pequenos lotes de terra no Brasil e prosperaram.

Passados mais de 120 anos que os imigrantes chegaram à cidade, na cidade os descendentes dos imigrantes iniciaram um novo movimento, um caminho inverso, conforme denominou Savoldi (1998) ao se referir ao movimento de retorno dos descendentes de imigrantes italianos para a terra de seus tataravôs.

No final do século XX, Criciúma tornou-se um ponto de partida de emigrantes para algumas regiões da grande Boston, concentrando-se nas cidades de Lowell, Sommerville e Everett (dados do campo) e para algumas cidades da Itália, onde há parentes e amigos que os auxiliam e estimulam na migração.

A crise do setor carbonífero (Teixeira 1996) enfrentada pela cidade, iniciada no final da década de 80 e agravada na década de 90, aponta para uma das razões que tornaram a cidade ponto de partida de inúmeros emigrantes em busca de trabalho na Itália ou nos Estados Unidos, embora não possamos reduzir a migração às motivações econômicas. Como demonstrarei a seguir, a emigração para a Itália e para os Estados Unidos também está associada ao imaginário presente na cidade, o qual constrói uma conexão entre os imigrantes do passado e os emigrantes do presente e principalmente ao desenvolvimento e ao amadurecimento de redes sociais ao longo do processo migratório.

Para pensarmos quais as conexões possíveis entre os imigrantes do passado e os emigrantes do presente e como são recriados os laços familiares quer seja na Itália, nos 
Estados Unidos ou no Brasil, as festas que comemoram a vinda das primeiras famílias para a região e atualizam as ligações com a terra natal dos tataravôs. Na região essas festas ganharam impulso, principalmente após o movimento de revitalização das festas italianas na região Sul do estado (Savoldi 1998) e por isso se constituem num material interessante. As festas de família mobilizam, em geral, os descendentes da terceira geração, os quais ainda têm lembranças dos bisavôs e ao mesmo tempo passam pela experiência de ver os/as seus filhos/as e sobrinhos/as partindo para a Itália e para os Estados Unidos. Com esse novo fenômeno, as festas de família reforçam as ligações com o imaginário da migração, pois, além de reviver o passado imigratório, também tentam incluir os novos emigrantes do final do século XX. Muitos vêm de longe para participar das mesmas. Isso pode ser observado no boletim elaborado por ocasião da festa de 120 anos de imigração de uma das famílias da cidade. O boletim intitulado "Informativo da Família Delucca - A comemoração aos
120 anos da imigração de Paolo Delucca ao Brasil" (junho/2000- n. ${ }^{\circ}$ 5)
encontramos uma parte dedicada aos imigrantes e na página seguinte
encontramos uma seção que inspirou o título desse artigo: "De Criciúma
para o mundo". Vejamos como são descritos os novos migrantes de
Criciúma:

"O engenheiro civil e surfista Renatinho DeLucca que aterrisou há trinta dias nos Estados Unidos, acaba de ser encontrado por dois amigos criciumenses em Boston, de uniforme de Mac Donald's e de vassoura na mão".

"A informação acima estampada no Jornal o Dia, (grifos da autora) de Criciúma, 18/05/2000, mostrou de forma simplificada as novas formas de emigração no mundo globalizado em que as pessoas, num mesmo dia, podem estar em quaisquer parte deste planeta e exercer a atividade que desejarem. Certamente nos tempos de Paolo (grifos da autora) a coragem de viajar rumo ao desconhecido, com seis filhos menores de 18 anos, sabendo que não haveria retorno, nos dá um exemplo de que, graças a essa coragem, possuímos hoje melhores condições de sobrevivência e que podemos voltar para casa ou estarmos em casa não importa onde estivermos" (Jornal Comemorativo Família Delucca, maio 2000).

Esse exemplo evidencia a tentativa de estabelecer uma ligação entre o passado e o presente através dos relatos de migração. No entanto, a “mística” em torno dos migrantes encobre, muitas vezes, as diferenças entre os migrantes do final do século XIX e os emigrantes desse início de século XXI e reforçam o imaginário da migração como uma “aventura”. Os imigrantes do século XIX vieram através de uma política migratória definida pelo governo do Império e mais tarde da República. Os imigrantes eram agricultores que migraram para ter acesso a terra, vieram para o interior do país para colonizá-lo e sua migração era legal, já que faziam parte de uma política imigratória nacional e grande parte da migração ocorreu em grupos familiares (Baldin 1987, Alvim 1999). 
Os emigrantes contemporâneos são em geral jovens, de nível secundário e muitas vezes universitário, que vão para a Itália porque lá podem trabalhar legalmente. Já a emigração para os Estados Unidos tem um caráter diferente, pois mesmo sendo portadores de passaporte italiano, com o tempo os migrantes ficam ilegais nos Estados Unidos. Há também uma maior diversidade étnica e de gênero, pois há uma maior participação das mulheres migrando sozinhas ou acompanhadas de parentes. Os migrantes partem para cidades industriais nos países de destino. As conexões entre aqueles que partiram e aqueles que ficaram também são mais freqüentes, pois num mundo globalizado as distâncias ficaram mais curtas com o desenvolvimento dos meios de transportes e comunicação. Os contatos mais freqüentes através de cartas, telefonemas e mais recentemente pela internet, indicam que os novos migrantes vivenciam a experiência de viver entre duas culturas. A construção de um campo de relações sociais entre o país de destino e os locais de origem sugere ainda o caráter transnacional (Glick-Schiller, Bash, Blanc-Szaton 1992) desses deslocamentos.

Por outro lado, a matéria evidencia a importância das redes familiares na migração, porque onde mais se concentram migrantes dessa mesma família é na região de Boston (cidades de Everett, Sommerville, Malden), o que revela a importância constituição e o amadurecimento de redes sociais, pois partem para onde já existem outros imigrantes brasileiros estabelecidos. A família espalha-se pelo mundo, mas em sua maioria, migram para cidades dos Estados Unidos ou da Itália, onde têm outros parentes ou conterrâneos.

As redes familiares construídas ao longo do processo atuam quando aqueles que já se estabeleceram nos Estados Unidos acolhem os que pretendem empreender essa difícil “aventura” evidenciando que esse projeto individual, em geral, está sustentado nas relações familiares. Nessas redes as mães, as esposas, as irmãs e namoradas são muito importantes, pois fazem circular as informações entre os demais membros das famílias.

Para demonstrar como atuam as redes familiares ao longo do processo migratório, apresentarei a trajetória da família Venturini e procurarei reconstruir o lugar de homens e mulheres, maridos e esposas, filhos e filhas. A trajetória dessa família revela como a migração familiar ocorre percorrendo diferentes caminhos, conforme destacou Hondagneu-Sotelo (1994) ao analisar o estabelecimento de famílias mexicanas nos Estados Unidos. Para a autora, a migração familiar pode ser classificada em três tipos: estágio familiar de migração, no qual a migração ocorre em etapas migrando inicialmente o marido depois a mulher e as crianças; migração da unidade familiar, na qual os casais e filhos migram juntos e migração 
independente quando migram os solteiros. Os vetores críticos desta tipologia são: gênero e geração.

A família Venturini é composta por descendentes de imigrantes italianos e espanhóis que chegaram à região de Criciúma no final do século XIX e que hoje vivencia a emigração de seus descendentes para a Europa e os Estados Unidos. A história dos descendentes, principalmente dos italianos, é muito valorizada, e os netos ainda se lembram das histórias contadas pelos “nonos” e pelas “nonas”. A família de Lorena é de classe média: o pai era um pequeno empresário e a mãe era professora aposentada no momento que decidiram migrar. Quando iniciaram a trajetória de migração, os filhos mais velhos estavam ingressando na faculdade.

Para reconstruir à trajetória da família Venturini, conversei com Lorena e Patrícia, filhas de José e Martina, e com as tias Manuela e Carmela. Embora não tenha falado com todos integrantes da família, as entrevistas forneceram um quadro do movimento da família entre os Estados Unidos e o Brasil.

Em 2001, quando iniciei as entrevistas com a família, dos cinco irmãos, três estavam nos Estados Unidos, os pais e um de seus irmãos estavam no Brasil como migrantes retornados e Lorena estava de malas prontas para a Europa, aguardando apenas a resolução do processo de cidadania italiana do namorado para ir para a Inglaterra. O destino dela modificou-se porque, em sua última ida para os Estados Unidos, em janeiro de 2000, havia sido barrada pelo Serviço de Imigração e deportada, pois tentou entrar com o passaporte italiano e, como não falava o idioma, desconfiaram de que ela era migrante.

A genealogia tentou captar essa família espalhada entre o Brasil, os Estados e a Inglaterra. Essa família de descendentes de italianos e espanhóis, vê os filhos e os netos viverem a experiência de viver entre dois lugares. A genealogia da família demonstra ainda a primeira geração de brasileiros nascidos nos Estados Unidos, uma tendência que foi observada no trabalho de campo na região de Boston. Os netos já visitaram a casa dos avós no Brasil e estão circulando entre as duas culturas. 


\section{Família Venturini}

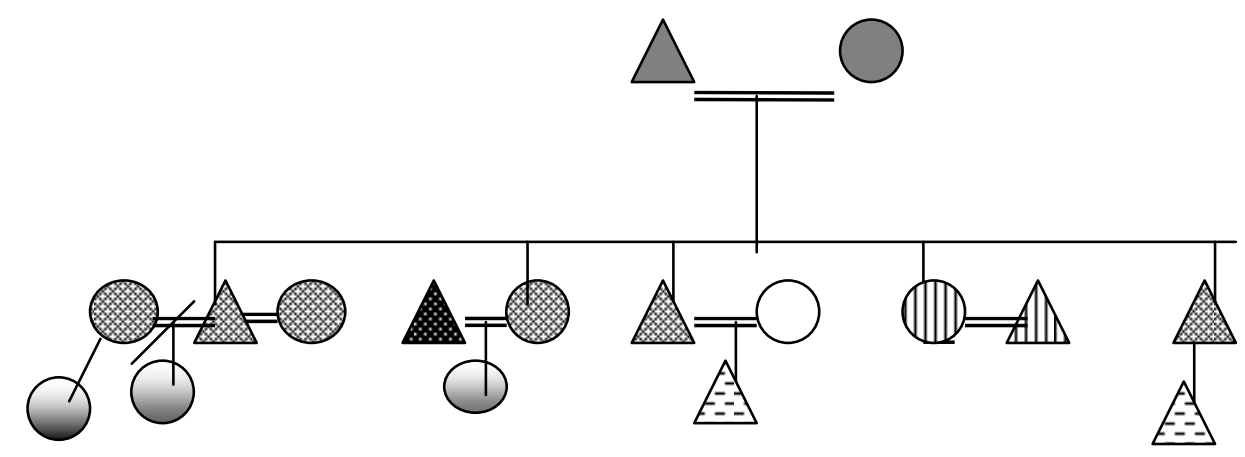

Brasileiro emigrante Retornado

Brasileiro/a emigrante nos Estados Unidos

[Dा Brasileiro/a emigrante na Inglaterra

Americano

Brasileira s/ experiência migratória

Filho de emigrante nascido no Brasil s/ experiência migratória

Filho de emigrante nascido nos Estados Unidos

Filho de emigrante nascido no Brasil s/ experiência migratória

Filho de emigrante nascido nos Estados Unidos

Lorena Venturini é uma jovem de 22 anos que já viveu desde os 14 anos entre os Estados Unidos e o Brasil, a sua trajetória se insere nas redes familiares de migração e revela como a migração torna-se um projeto familiar, vejamos sua descrição de como a família foi se tornando migrante.

\section{Lorena Venturini:}

"Meu irmão, ele e mais outro foram na cara e na coragem e a mãe tinha um primo lá. Aí foram e ficaram dois anos. Ficaram direto sem voltar e de vez em quando telefonava, claro. Daí a mãe resolveu que ela e o pai iam lá passear, iam passear e voltar. O pai tinha loja de calçados e não podia sair. Aí a minha mãe e o outro irmão mais novo... Aí foi assim, eles iam primeiro, a gente não ia vender nada, eu o meu irmão e o meu pai tomamos conta de tudo, se eles gostassem de lá a gente venderia as coisas e ia embora para lá também. Ai foram ficaram um mês e meio, um mês passeando né? Ai a mãe ligou dizendo que tinha adorado que não voltava mais e que era para a gente vender as coisas, dar um jeito em tudo, daí um mês e meio meu pai vendeu a loja para a minha tia e a gente alugou esta casa e a minha irmã mais velha não quis ir. Aí a minha irmã mais velha ficou morando com a avó e foi eu e o pai. Tava quase toda a família lá já fazia uns 8 meses e a minha irmã resolveu ir também. 
Ela não tinha visto daí veio visto de 3 meses aí ela no pode pensar muito teve que ir rapidinho. Toda a família inteira a gente ficou 2 anos. A família retornou para o Brasil e os filhos mais velhos permaneceram na região de Boston ”

A família Venturini foi se estruturando entre os dois lugares, estabelecendo uma rede de relações onde pais e filhos redefiniram suas posições, ao longo do processo. Durante a permanência nos Estados Unidos, o pai sentiu-se com menor autoridade sobre os filhos, o que foi um dos fatores que o motivou a retornar ao Brasil: "não tinha mais o controle dos meus filhos/as” relatou em sua entrevista. Ao mesmo tempo, os filhos e filhas sentiam maior autonomia para decidir onde viver. Se nos Estados Unidos isso foi fonte de conflito, em alguns momentos, atualmente sempre retornam a casa dos pais. Os mais jovens como Lorena e Matheus circularam mais entre os Estados Unidos e o Brasil e agora, Inglaterra, no caso de Lorena. Segundo o relato dos pais, os filhos continuaram a ajudar a família, mesmo depois de estabelecidos no exterior. Em contrapartida, são os pais que administram os investimentos e também cuidam das netas quando vêm ao Brasil. O relato da família Venturini é interessante para compreendermos com se constroem e se consolidam as redes de migração.

Essas redes sugerem a pertinência da análise de Yanagizako (1977) para nos ajudar a compreender como se articulam as redes familiares dos imigrantes criciumenses. Analisando duas gerações de imigrantes japoneses, Yanagizako (1977) demonstrou a importância das mulheres centradas nas redes de parentesco. Assim ao invés de perceber essa atuação das mulheres nas relações de parentesco como matrifocalidade, a autora aponta para a centralidade das mulheres nas redes de parentesco interconectando outros domicílios.

O relato da família Venturini nos leva a pensar que também nesse caso, as mulheres atuam como articuladoras de redes de parentesco, pois se observa um padrão semelhante que sugere que essa rede feminina se constrói da mesma forma. Os pais e irmão de Marcos quando migraram, embora tenham ido encontrar com o filho mais velho que já estava estabelecido nos Estados Unidos, não encontraram nele o apoio que esperavam. Marcos já estava casado e havia constituído uma nova família, o que criou conflitos com a família. Diante desse fato, a segunda filha, que migrou oito meses depois, foi quem assumiu ficar junto com a família e ajudar a realizar os objetivos. A mãe logo arranjou um emprego de faxineira junto com uma prima materna com quem trabalhou inicialmente antes de entrar para uma firma de faxina na região de Boston. Por outro lado, Lorena nos relata que sempre que retornou aos Estados Unidos ficou na casa da irmã, mesmo o irmão morando na mesma cidade. A tia materna quando migrou para os Estados Unidos, também ficou na casa de 
Patrícia nos primeiros tempos e foi ela que ajudou a arranjar trabalho no mesmo local onde trabalhava, uma loja de confecções. Segundo os pais, as filhas mantêm-se em contato mais freqüente, e embora os filhos também ajudem, parece que contam mais com as filhas.

Essa situação também foi observada em outras famílias entrevistadas. Na família Cruz também o primeiro a migrar foi o irmão mais velho, que se manteve em contato com a família no Brasil. No entanto, foi só quando a irmã migrou é que os outros irmãos e inclusive a mãe resolveram migrar, também para a região de Boston. Letícia Cruz, após ficar viúva, emigrou com o filho pequeno para tentar uma vida melhor para os dois. Depois que emigrou foram sua mãe, a irmã mais nova e o irmão. Todos moraram na casa do irmão mais velho por um tempo, mas aos poucos a irmã saiu e os outros irmãos também. Atualmente é a irmã quem centraliza as relações familiares, a mãe trabalha com ela na faxina, ajuda à irmã e ao irmão mais novo que migrou por último.

No caso da família Ramella, ocorreu um arranjo diferente, pois o casal Ramella recebeu o irmão e o primo do marido, mas nesse caso eles não permaneceram por muito tempo, segundo o casal, eles não se adaptaram ao ritmo de vida e trabalho nos Estados Unidos. Embora esses dados sejam de natureza qualitativa, evidenciam a importância dessas redes de parentesco que ligam mãe, filhas, netas não apenas entre si, mas também através delas os pais, irmãos e primos se ligam com os familiares sugerindo que, assim como nas gerações de migrantes japonesas, pode-se perceber essas mulheres centradas nas redes de parentesco entre os imigrantes criciumenses.

As entrevistas realizadas revelam que os homens que emigram, muitas vezes deixando suas esposas, têm que confiar a estas a administração do dinheiro que remetem ao Brasil. Assim muitas mulheres tornam-se empreendedoras no Brasil, o que muitas vezes gera desconfiança dos outros familiares, ou do próprio marido. O medo de trabalhar e com o tempo perder a família no Brasil é recorrente entre esses migrantes, uma situação com a qual seus bisavôs nunca imaginaram passar...

As mulheres por sua vez, quando migram solteiras, encontram um outro mundo para conhecer e vivenciar bem diferente dos horizontes colocados pela cidade. Algumas entrevistadas eram jovens universitárias, solteiras que queriam ter outras experiências na vida, que não apenas casar e ter filhos que parece ser o destino reservado aquelas que ficaram. 
Algumas delas quando retornam ao Brasil e encontram suas amigas casadas se perguntam quando vão para de ir e vir.

Os casamentos continuam a ocorrer, mas é interessante observar que em geral os homens casam-se com as mulheres brasileiras, muitas vezes da mesma cidade, enquanto as mulheres brasileiras, tanto nos Estados Unidos quanto na Itália, casam-se mais com os estrangeiros, o que pode levantar questões sobre quais expectativas e representações existem sobre a mulher brasileira, geralmente associada à idéia de boa esposa e mãe.

Enquanto seus filhos/as e netos/as trabalham pelo mundo, as nonas e mães tocam sua vida, preparam a casa para recebê-los, muitas vezes administrando o dinheiro que é enviado. Essas questões precisam ser analisadas com mais detalhe mas sugerem vários arranjos familiares nesse processo. O contato com o Brasil entre os emigrantes e os que ficam é mantido através das cartas, fotos, telefonemas e mais recentemente através da internet, atualizando e reforçando a idéia do projeto familiar, econômico e afetivo que é a imigração. Fazendo dessa forma, com que o projeto de emigrar não seja visto apenas como desestruturador das relações familiares, mas como uma realidade que possibilita novos arranjos familiares e de gênero.

Esse trabalho demonstrou que os estudos de gênero podem trazer contribuições importantes para compreender os movimentos migratórios contemporâneos. Para tanto, demonstrou inicialmente como as mulheres ficaram subsumidas na categoria migrante. Dessa forma não se percebeu, nos estudos clássicos de migração, que as mulheres podem acompanhar os homens como esposas, mas nem sempre reescrevem este caminho. No passado e no presente, embora, em sua maioria migrem em grupos familiares, as mulheres também migraram sozinhas para fugir de poucas oportunidades ou discriminações nos locais de origem.

Além disso, ao incorporar a categoria gênero na análise dos fluxos migratórios, a migração deixou de ser vista apenas como uma escolha racional de indivíduos sozinhos e emerge envolvida em redes de relações sociais, como uma estratégia de grupos familiares, de amigos ou pessoas da mesma comunidade. Nesse contexto, as mulheres e os homens, em diferentes momentos aparecem como os "elos" que ligam - aqui e lá - através de redes sociais que ajudam nos primeiros momentos na sociedade de emigração e também ajudam a manter os laços com o lugar de origem. 


\section{RESULTADOS}

Os fluxos migratórios para os EUA via México estão relacionados com diversos atores. Neste sentido, foram considerados, neste estudo, aqueles cuja opinião venham a expressar a realidade dos emigrantes que se propõem adentrar no mencionado país e que, diretamente ou indiretamente, interferem nas estatísticas oficiais e nas receitas de Agências de Viagens. Nesse sentido, os resultados da pesquisa focarão a tríade: agências de viagens, emigrantes e atravessadores (coyotes).

Nos últimos dias de janeiro do corrente ano foi possível visualizar, em rede nacional, a situação por que tem passado os brasileiros que arriscaram tudo por uma entrada nos EUA de forma ilegal. Os riscos que foram apresentados em reportagens por diversos telejornais (Veja, janeiro de 2003 e Jornal Nacional, janeiro de 2003) são de diversas dimensões: financeiras, pois normalmente o cidadão que se propõe a facilitar a travessia cobra altas montas; físico, uma vez que o caminho é distante e repleto de perigos naturais; legais, pois, na maioria dos casos têm ocorrido prisões, gerando problemas diplomáticos entre os dois países.

Neste sentido, a pesquisa aplicada aos emigrantes demonstra o perfil sócioeconômico-financeiro, os motivos que os levaram à emigração bem como a consciência dos riscos envolvidos nesta aventura e as formas utilizadas para chegar até o destino.

Para tanto, observando o gráfico 1.1 pode-se facilmente verificar que 37,5\% das pessoas que estão por fazer a emigração são de idade jovem, ou seja, compreendem a classe de 21 a 30 anos sendo pessoas que estão posicionadas diante de um cenário de desemprego generalizado e que, possivelmente, não conseguiram ingressar no mercado de trabalho. 


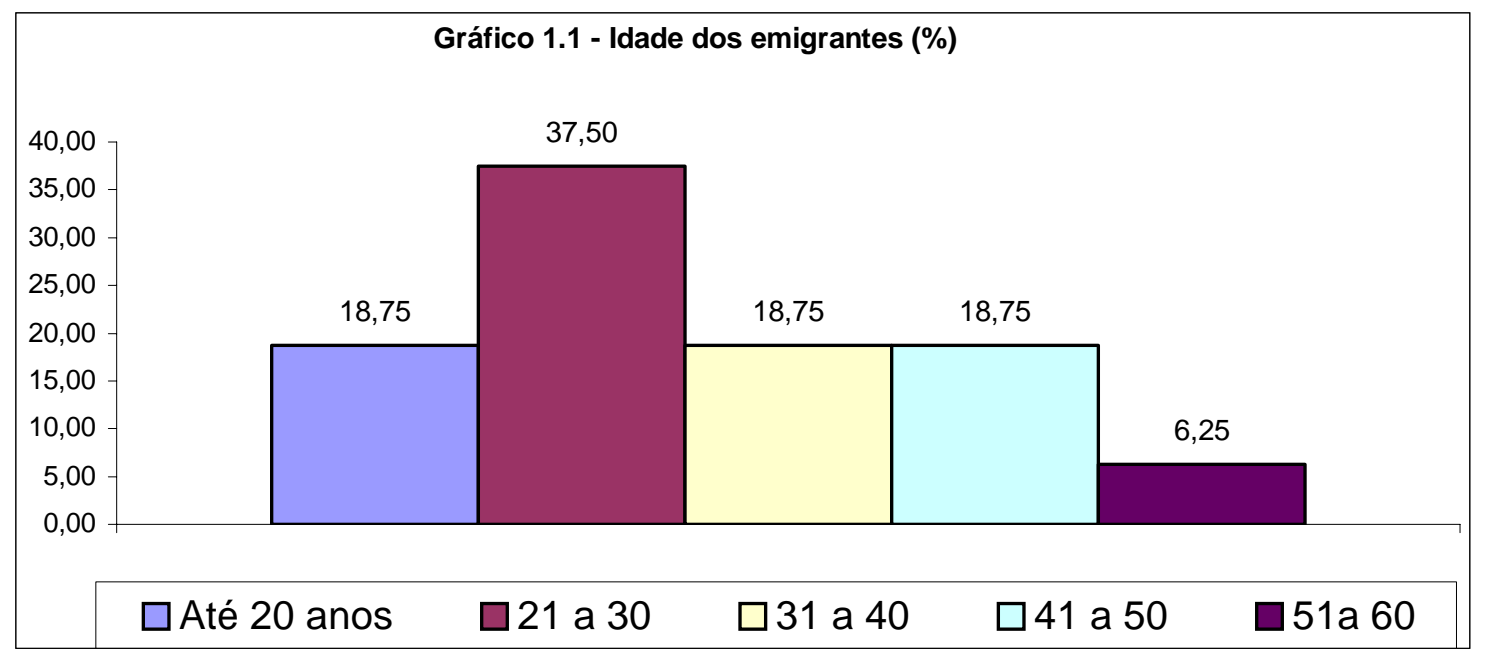

Essas pessoas são, em sua maioria (62,5\%) do interior de Goiás, conforme apresenta o gráfico 1.2. Certamente essa demanda é maior pela própria dificuldade de emprego em cidades de menor tamanho e cujas economias dependem basicamente da agricultura e pecuária.

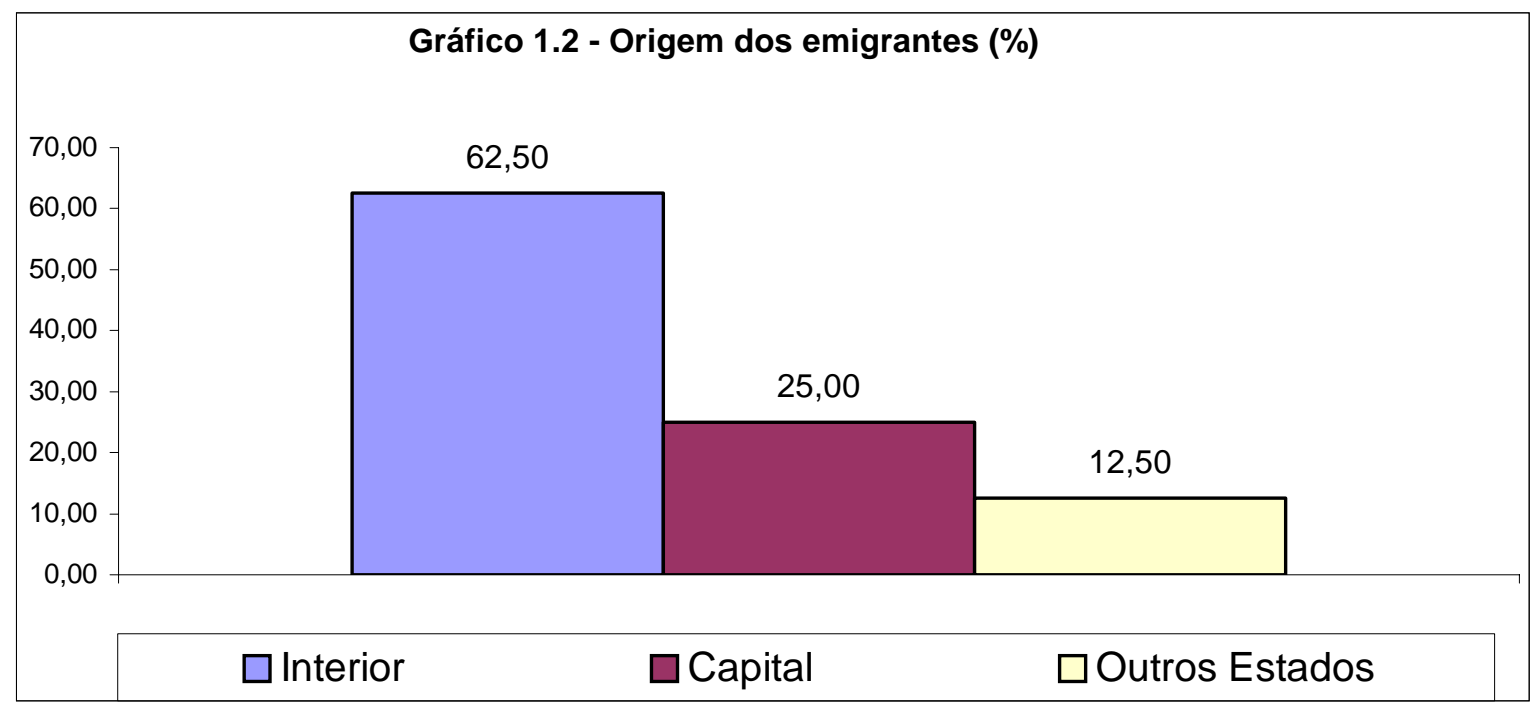

Buscando avaliar a profissão dos futuros emigrantes, o gráfico 1.3 demonstra alguns dados interessantes. Em primeiro lugar, a maioria dos entrevistados (31,25\%) estão posicionados nas mais variadas profissões (auxiliares administrativos, professores, bancário, serralheiro, balconista, etc.), em segundo lugar, apareceu um dado interessante, onde se observa que 25\% são agricultores/fazendeiros. Aqui, talvez caberia uma reflexão sobre os motivos que tem levado proprietários de terras a abandonarem seus negócios e ingressarem numa cultura totalmente diferente, induzindo assim, a conclusões sobre a incapacidade do governo brasileiro sobre a política agrária e de agricultura. Da mesma forma e em terceiro 
lugar, aparecem os comerciantes, cujo percentual de 18,75\% sugere a mesma reflexão já exposta.

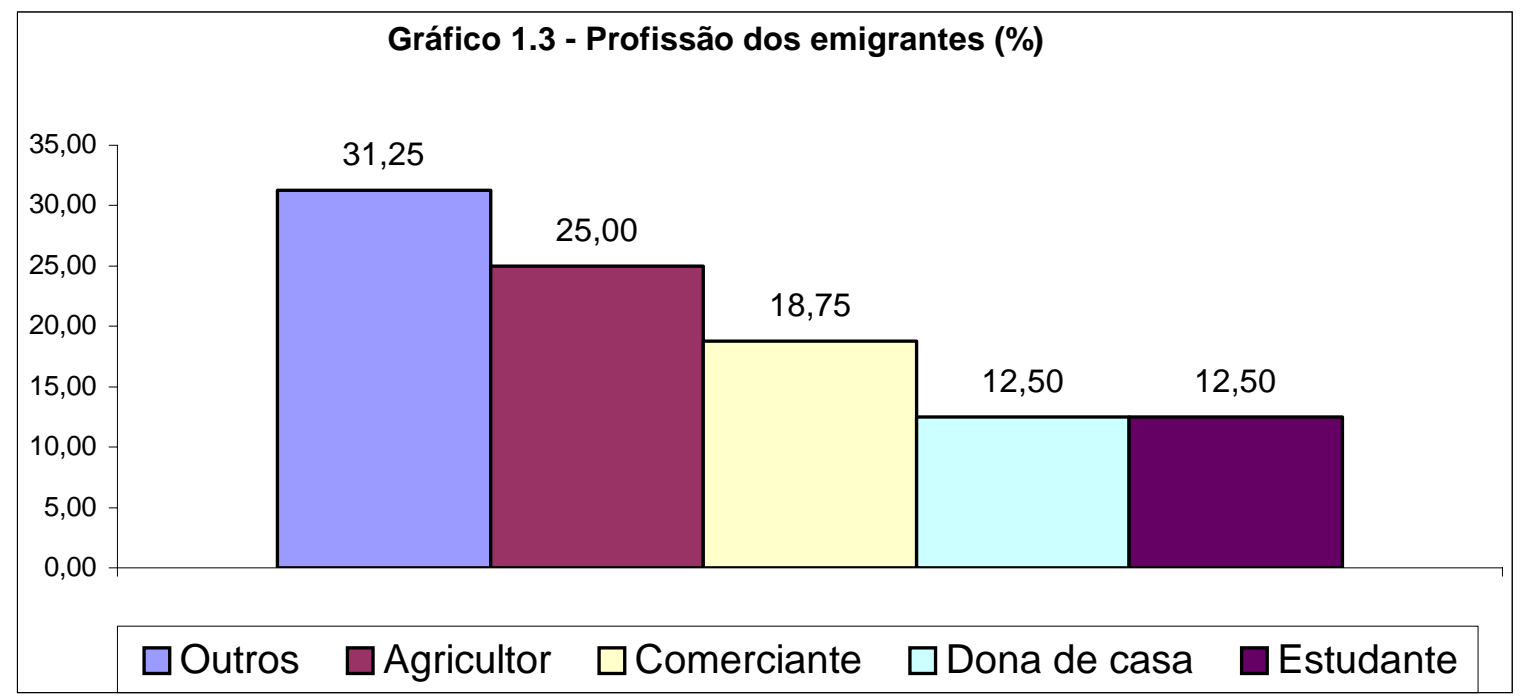

Quanto ao estado civil, observa-se no gráfico 1.4 que a maioria dos entrevistados está enquadrada como solteiros (43,75\%) que, unidos aos percentuais de separados e viúvos, chega-se a um total de 62,5\%. Esses números demonstram que as pessoas atualmente dispostas e emigrarem para os EUA são, em sua maioria, desimpedias civilmente ou que ainda não constituíram família.

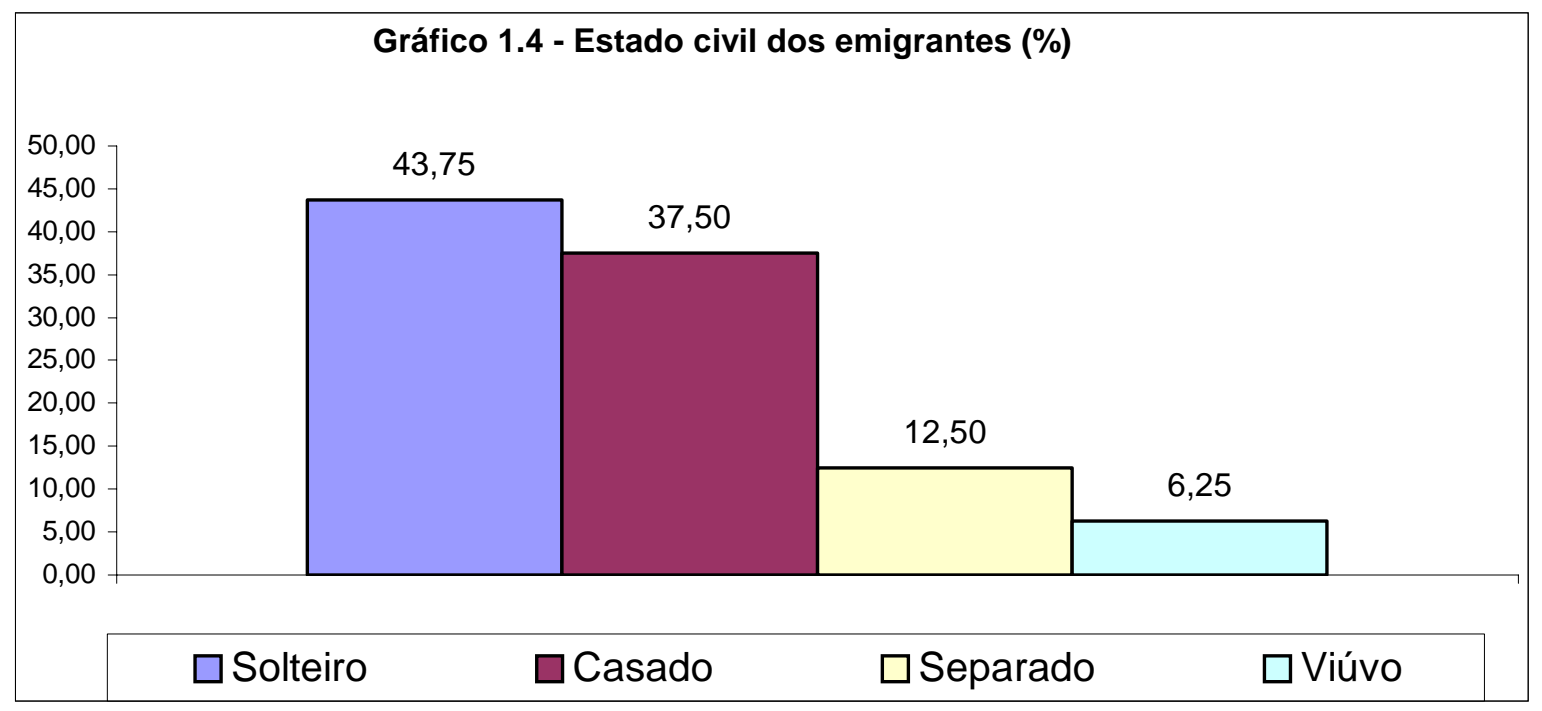

Do total de pessoas entrevistadas, a maioria possui, ou o segundo grau completo (56,2\%) ou o nível elementar (25\%). Assim, é possível notar claramente o perfil de quem deseja migrar: ou são pessoas que chegaram ao final do ensino médio e que de alguma forma 
estão impossibilitados de dar continuidade aos estudos e conquistar uma profissão que lhes dê dignidade, ou são pessoas que mal concluíram o ensino elementar, e portanto estão ainda mais distantes dessas possibilidades.

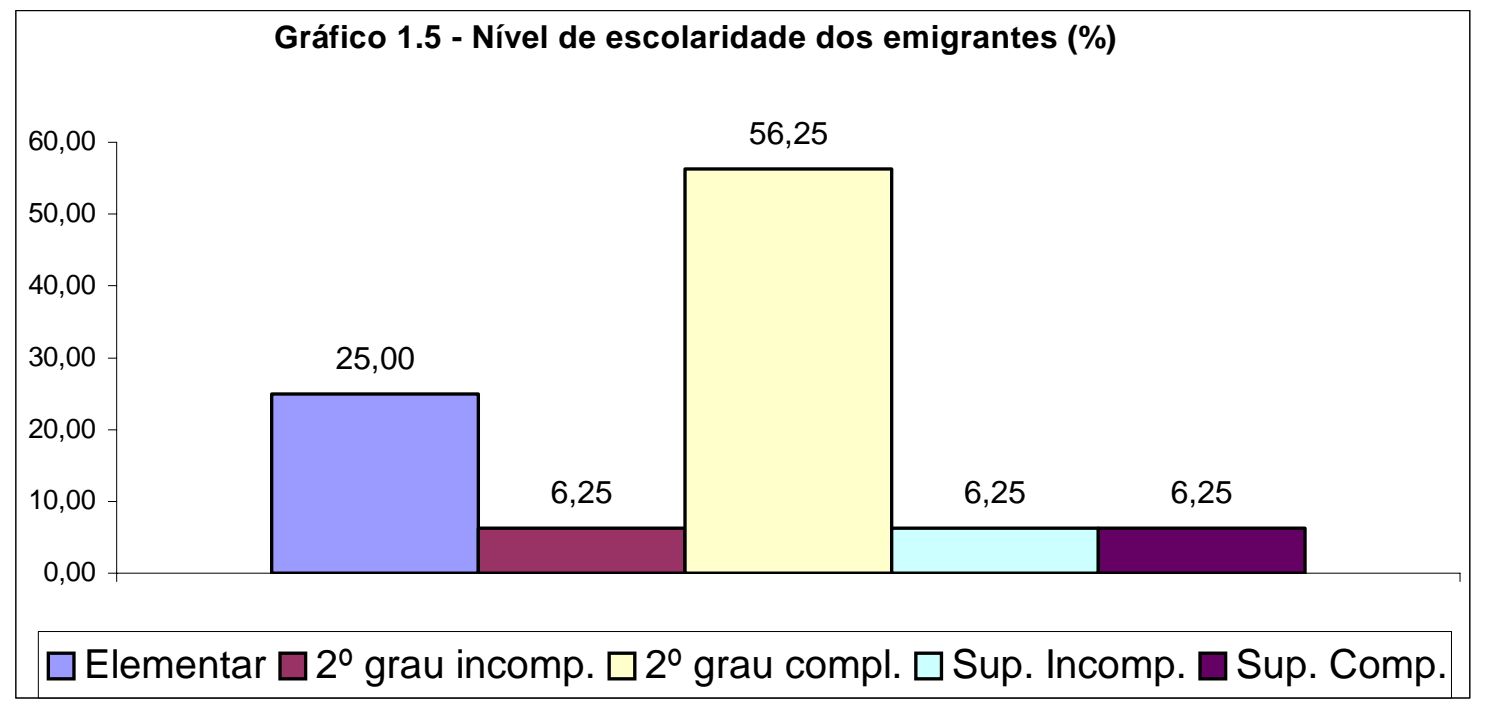

Entretanto, mesmo diante dos dados apresentados anteriormente, o gráfico 1.6 traz uma contradição, pelo menos quanto ao raciocínio lógico deste estudo, ao demonstrar que 68,75\% dos entrevistados estão empregados. Talvez isso ocorreu pelo perfil da maioria, que segundo os dados, são autônomos.

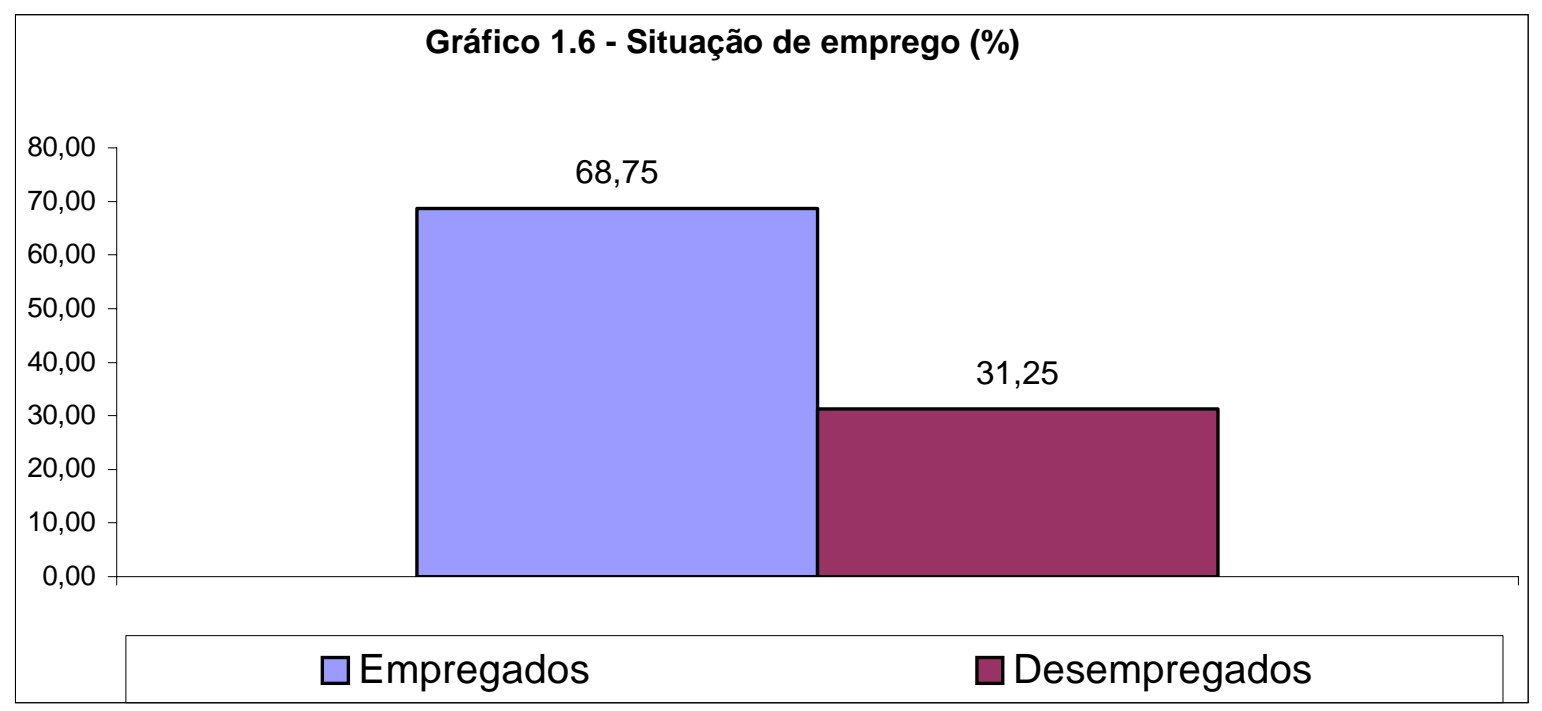

Partindo para um enfoque mais específico da pesquisa, é possível verificar no gráfico 2, os principais motivos que levaram os entrevistados a migrarem para um país economicamente mais rico. Dentre as várias respostas encontradas, que na verdade são razões 
bastante imbricas, destaca-se, a vontade insaciável de melhorar de vida (28,57\%), a falta de dinheiro (19,05\%), encontrar familiares que já estão nos EUA (14,29\%) e o desemprego (também 14,29\%). Assim, são pessoas que estão, de fato, desacreditadas com o futuro do Brasil e que chegaram a difícil decisão de abandoná-lo como forma de encontrar horizontes que lhes tragam mais oportunidades.

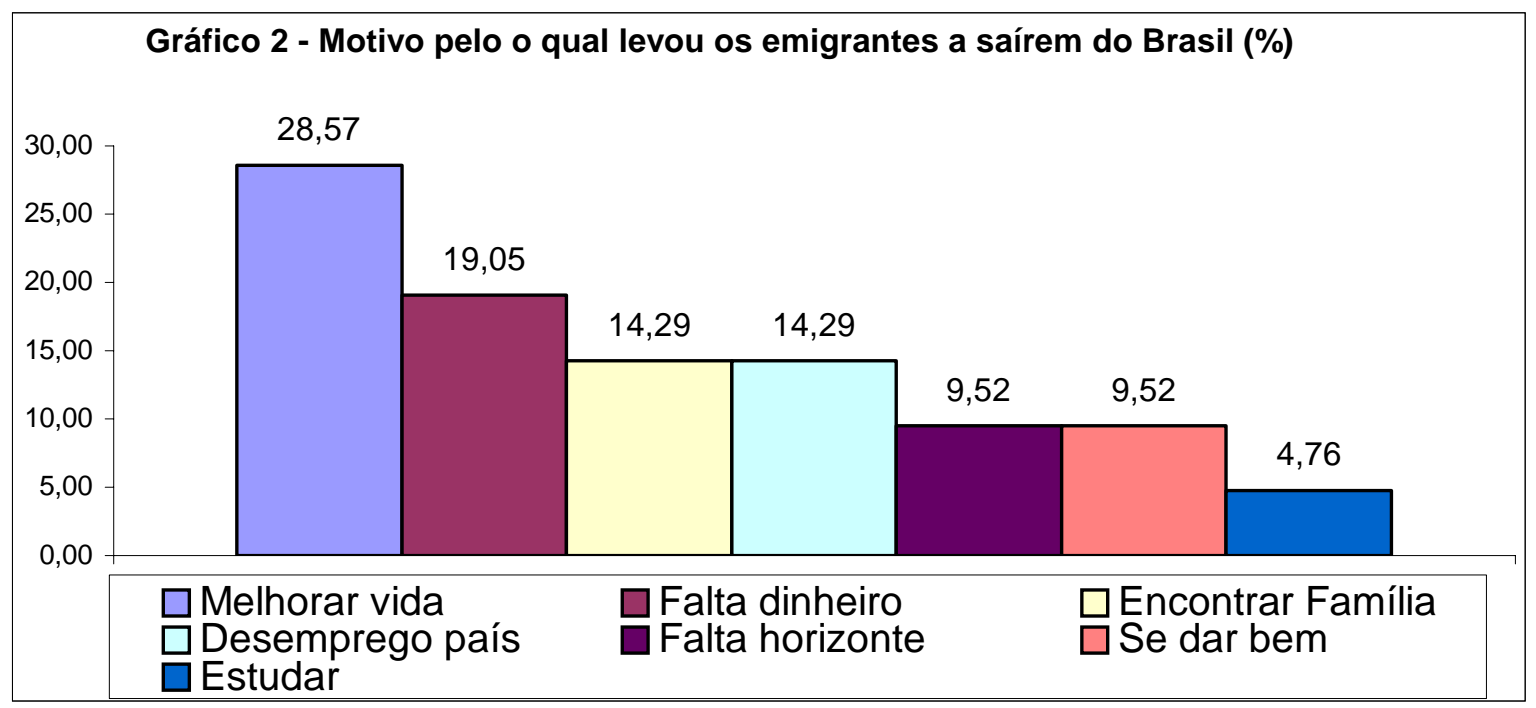

Interessantes são as formas utilizadas por estas pessoas para bancar todo o percurso de migração. É válido relembrar que o custo total, atualmente, gira em torno de 10.500 dólares por pessoa. Dessa forma, a primeira indagação é: como pessoas que estão, teoricamente, desempregadas ou descapitalizadas, vão obter um valor considerável de capital para financiar uma viagem aventureira e repleta de riscos?

Pois, bem, o gráfico 3 demonstra que a principal origem desses recursos é, em primeiro lugar, os parentes (26,09\%) entendidos como capital social (redes de parentesco), em segundo lugar a venda de tudo que possuía (21,74\%), em terceiro lugar por empréstimos (13,04\%) e pela venda de imóveis (13,04\%). Assim, além de todos os riscos mencionados, os futuros emigrantes ficam sujeitos a um estado pior, caso ocorra frustração na tentativa de migração. 


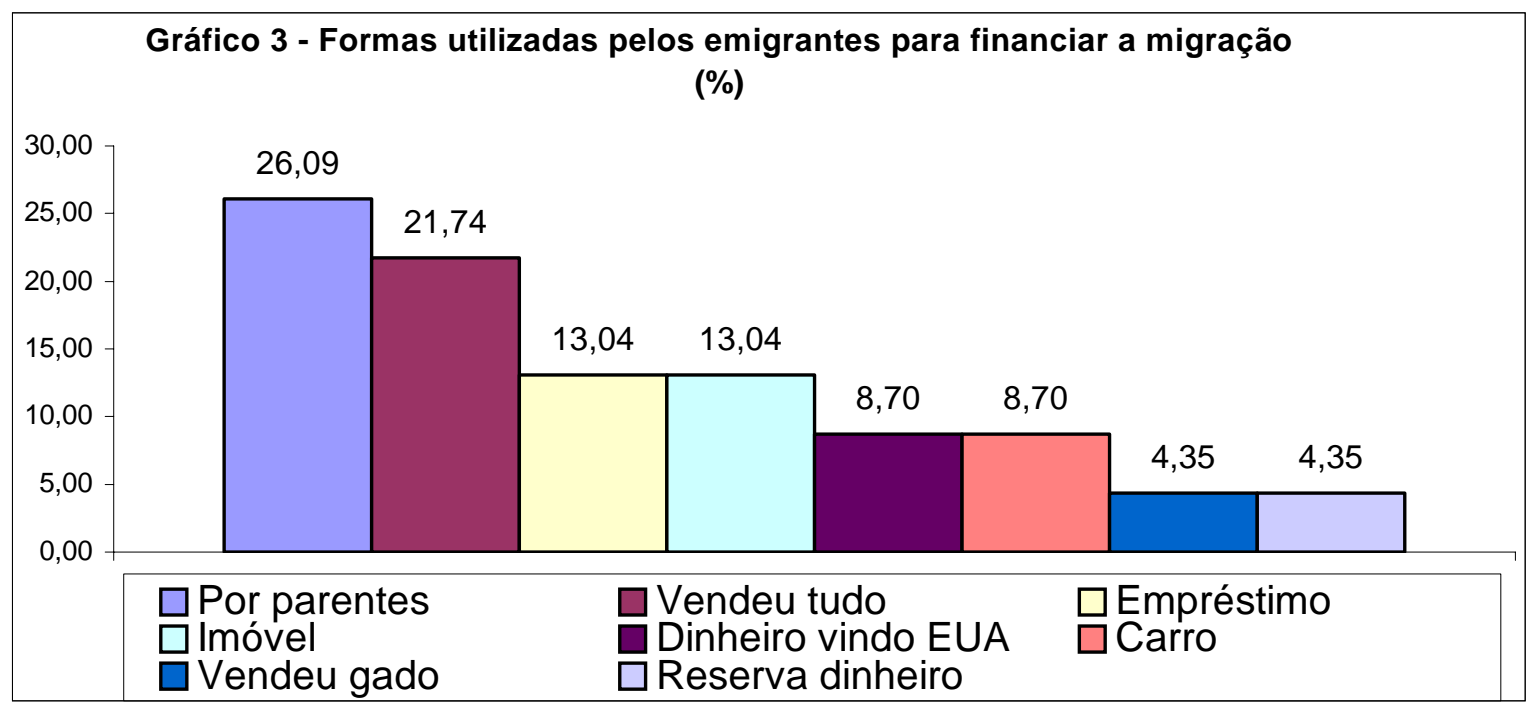

No que se refere aos objetivos e expectativas dos emigrantes ao pisarem em chão norte-americano, o gráfico 4 demonstra que 41,67\% estão naquele país exclusivamente para ampliar o capital que já dispõem, ou seja, "ganhar muita grana”; 25\% pensam na palavra trabalho, não considerando o “como” , “o quanto” ou “em qual condição” vão trabalhar e 20,83\% pretendem casar e viver nos EUA, o que é um dado preocupante, já que é um número significativo de pessoas que desacreditam totalmente no Brasil, ou seja, são pessoas que perderam ou por questões culturais, nunca tiveram o menor patriotismo.

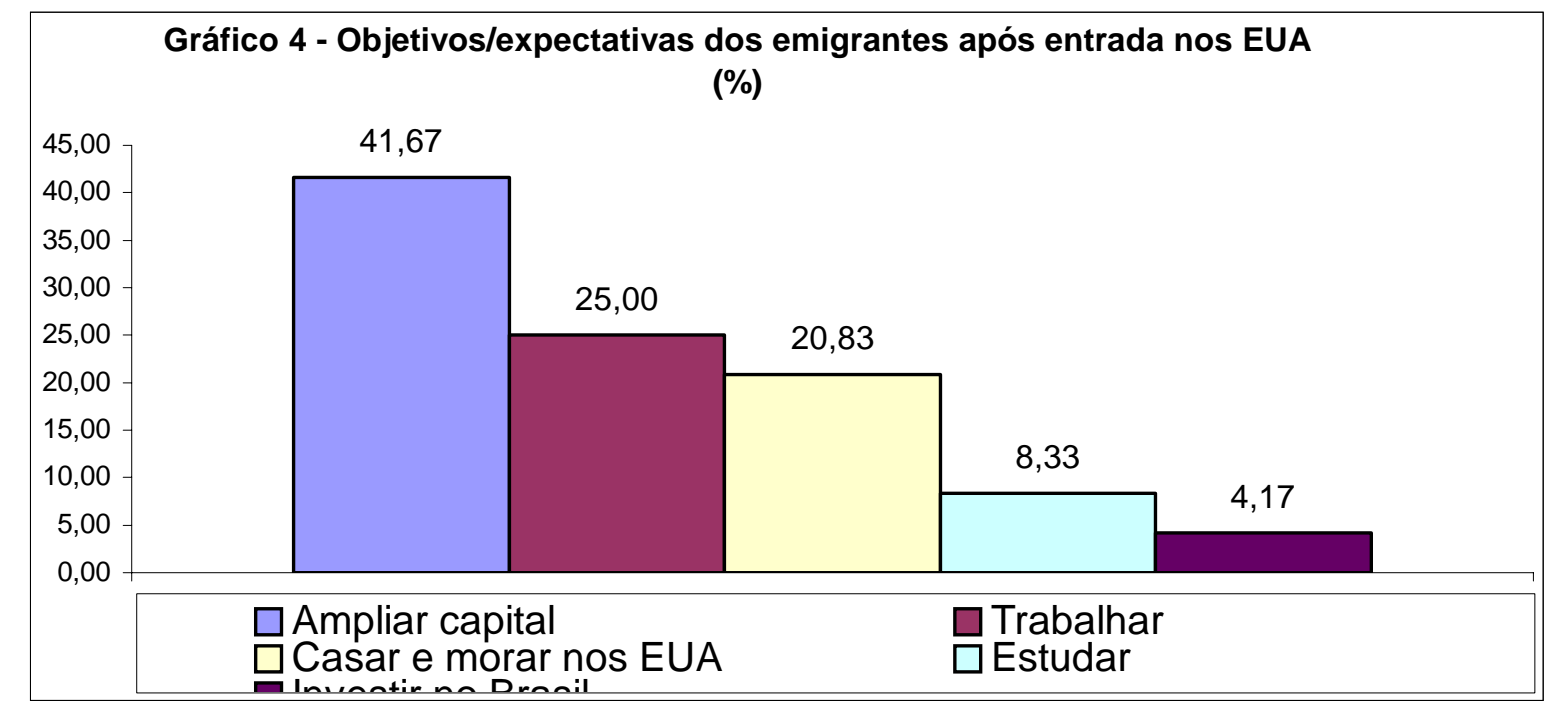

Outra informação importante da pesquisa, é a indicação de que a maioria dos entrevistados está disposta a migrar para os EUA a convite de parentes e amigos que estão naquele país. Essas redes parentesco-sociais têm se intensificado uma vez que elas permitem que os futuros emigrantes se ajustem à nova realidade dos EUA de forma facilitada, sendo 
que em grande parte dos casos, as pessoas que já possuem parentes naquele país, viajam com uma expectativa de trabalho pré-combinado. No gráfico 5 fica claro que $50 \%$ deles conhecem até 3 pessoas já estabelecidas naquele local e 43,75\% conhecem mais de seis pessoas. Assim, é possível imaginar que, certamente, os futuros emigrantes já possuem orientação sobre a viagem, a estadia, o trabalho e a vida naquele país.

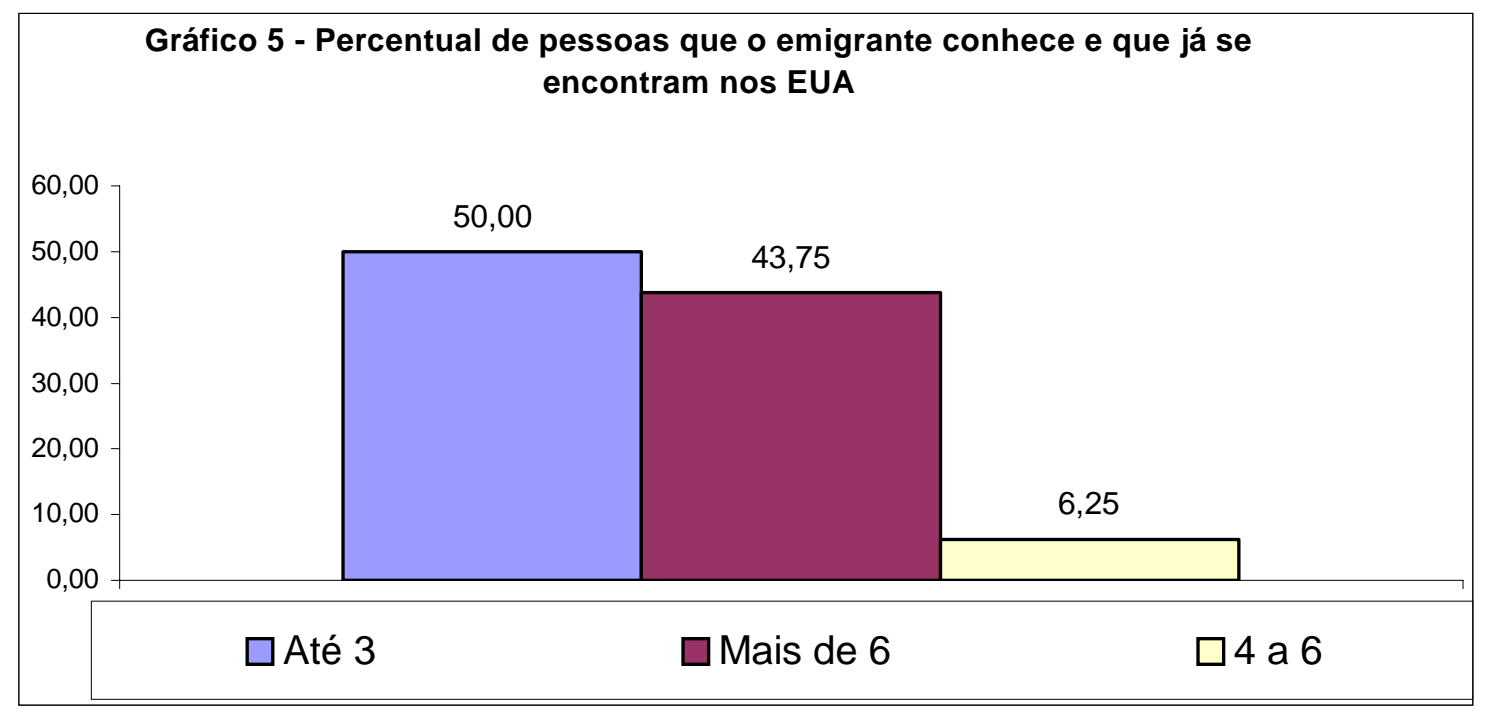

Ao serem indagados sobre o conhecimento de possíveis casos frustrados, o gráfico 6.1 revela que $81,25 \%$ dos entrevistados já ouviram falar ou conheceram diretamente casos como este. Assim, confirma-se dois fatos: primeiro, que essa forma de migração é altamente arriscada e em sua maioria resulta em insucesso e perda do capital gasto; segundo, que as pessoas que estão se propondo a esta viagem, tem consciência destes riscos, como afirma em entrevista, o sr. José Flores; “já tentei mudar para os Estados Unidos de forma ilegal, atravessando o deserto do México, o coyote me garantiu que eu seria colocado dentro do país, mas fiquei perdido e sem amparo, sem saber falar o inglês e o espanhol fui presa fácil [...] e acabei sendo deportado, mas... já estou conseguindo outra grana e vou arriscar novamente, mesmo tendo perdido tudo na primeira vez”. 


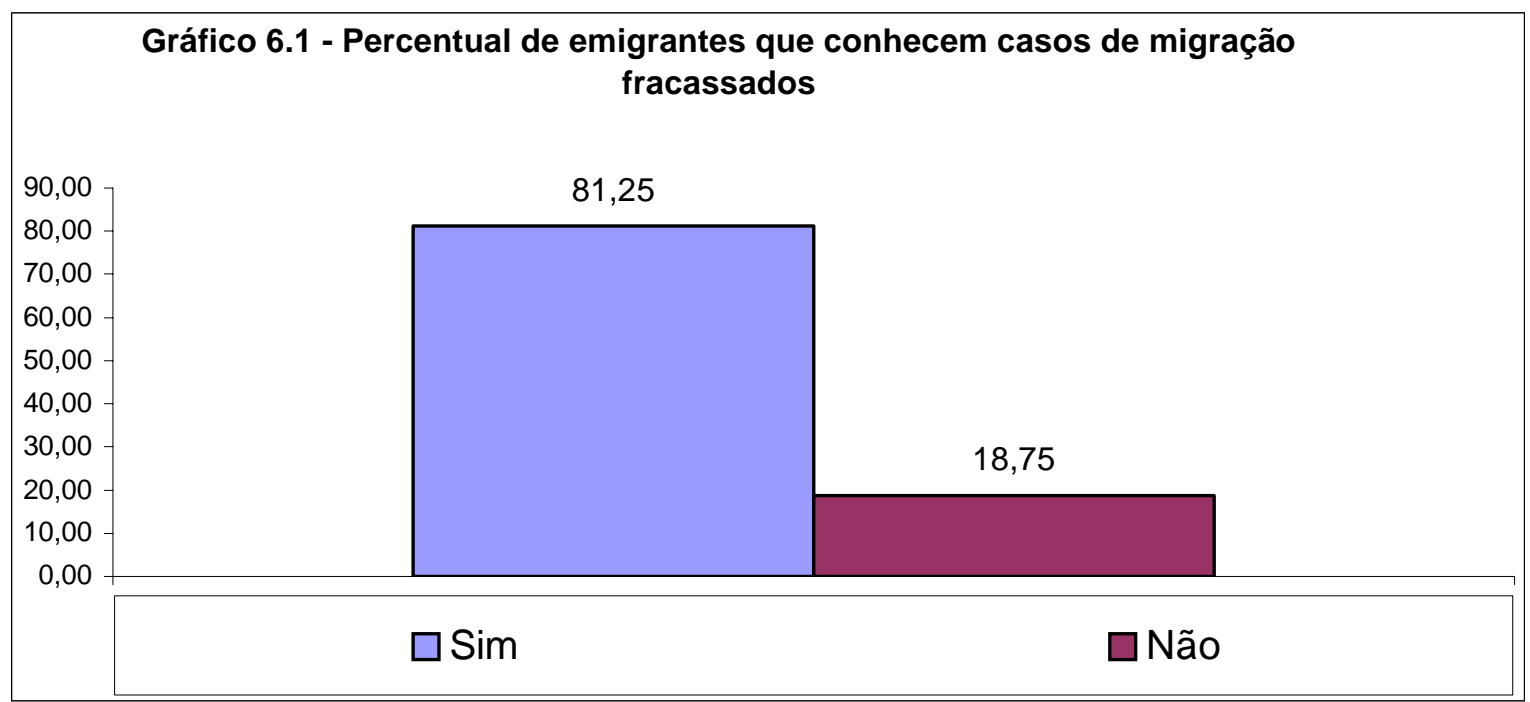

Do total de pessoas conhecidas e que fracassaram na tentativa, conforme demonstrado no gráfico anterior, os entrevistados revelam no gráfico 6.2 que $50 \%$ delas não vieram a perder todos os bens, $25 \%$ de fato perderam tudo e $25 \%$ não sabem se esse fato ocorreu.

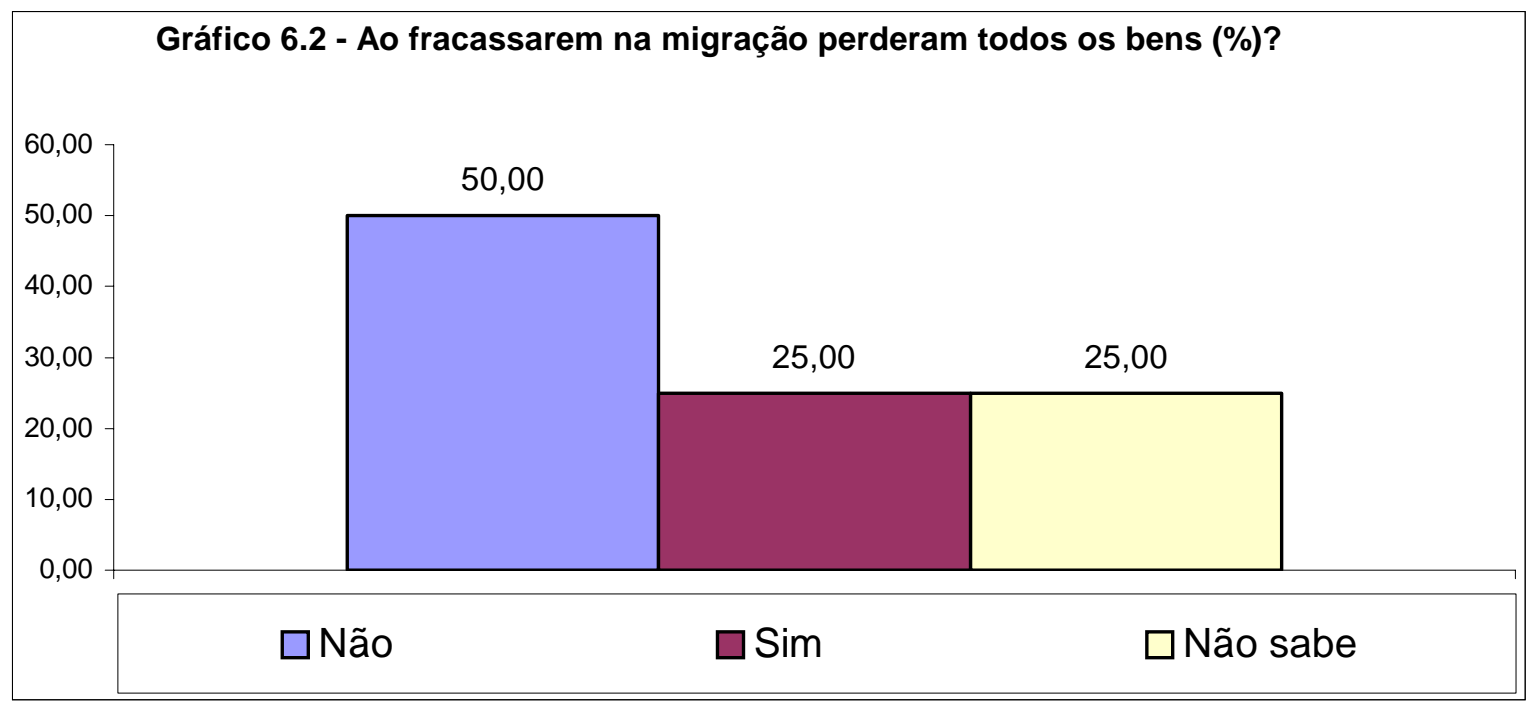

Ao tentar verificar como os futuros emigrantes adquiriram suas passagens aéreas, lhes foi inquirido os meios adotados para proceder este processo. Do total, 81,25\% revelaram que a compra das passagens foram diretamente nas agências de viagens; 12,50\% originaram de coyotes/agentes de viagens, ou seja, a negociação foi entre estes dois atores e apenas 6,25\% foram adquiridas diretamente de um coyote, conforme apresentado no gráfico a seguir. Considerando que este estudo enfoca as agências de viagem, este dado é bastante 
preocupante, uma vez que os empresários destas empresas costumam manter relações com coyotes, o que indica a dependência deste nicho.

Ao ser entrevistada, a sra. Ana Maria afirmou que "foi muito fácil conseguir uma pessoa para me providenciar minha viagem, isso porque me indicaram um agente de viagem que fazia tudo, inclusive a travessia pelo México. Então comprei o bilhete em sua própria agência e agora aguardo para viajar na próxima semana, estou temerosa, mas a precisão é maior. Não irei sozinha, tem mais duas amigas. Passamos um ano juntando dinheiro e o restante, meu irmão que mora lá nos EUA me enviou”

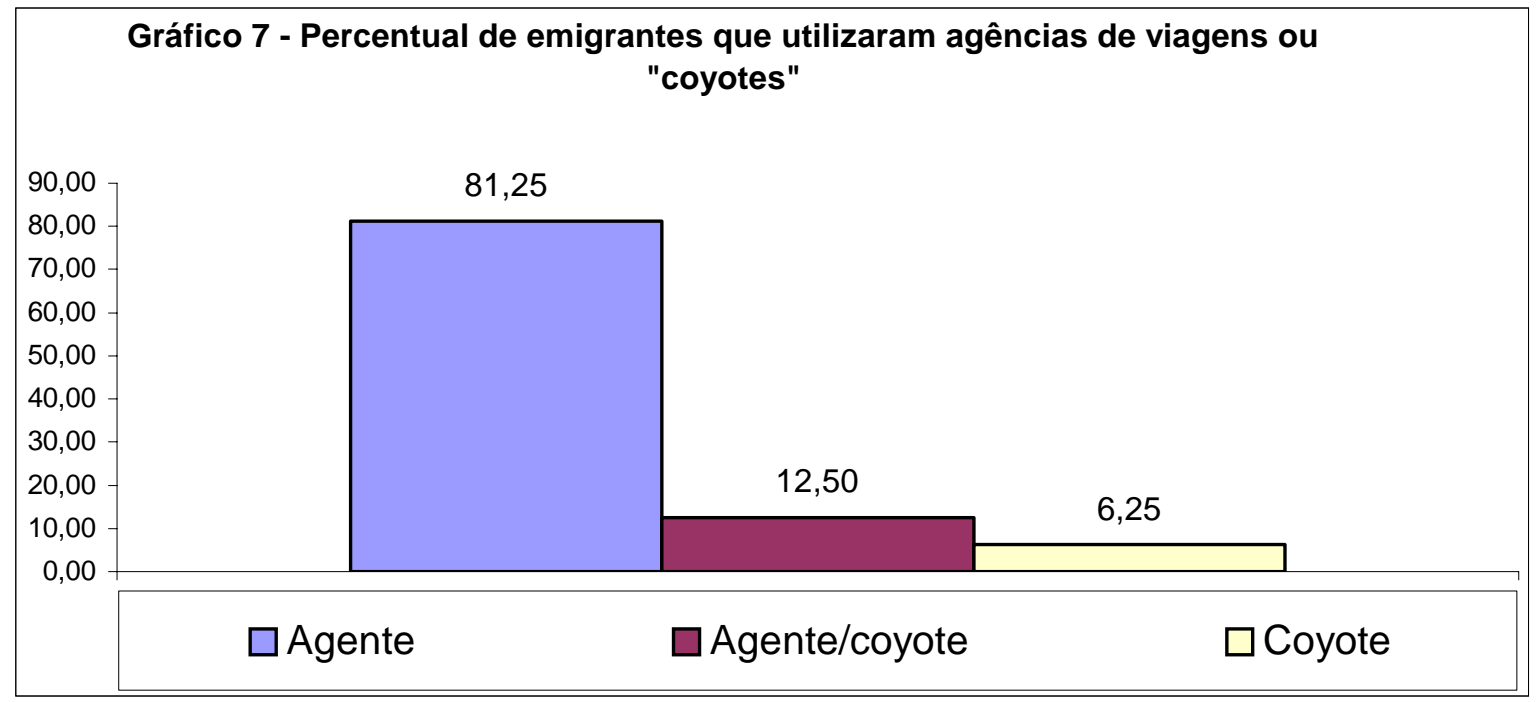

Procurando verificar o nível de relação entre os futuros emigrantes com os Agentes de Viagens, os Gráficos 8.1, 8.2 e 8.3 exploram essencialmente a comunicação entre estes atores sobre a viagem. Dessa forma, nota-se que a maior parte $(62,50 \%)$ das pessoas que compram seus transportes nas agências de viagem comunicam aos agentes e funcionários a intenção de fazer o trajeto para os Estados Unidos via México. 


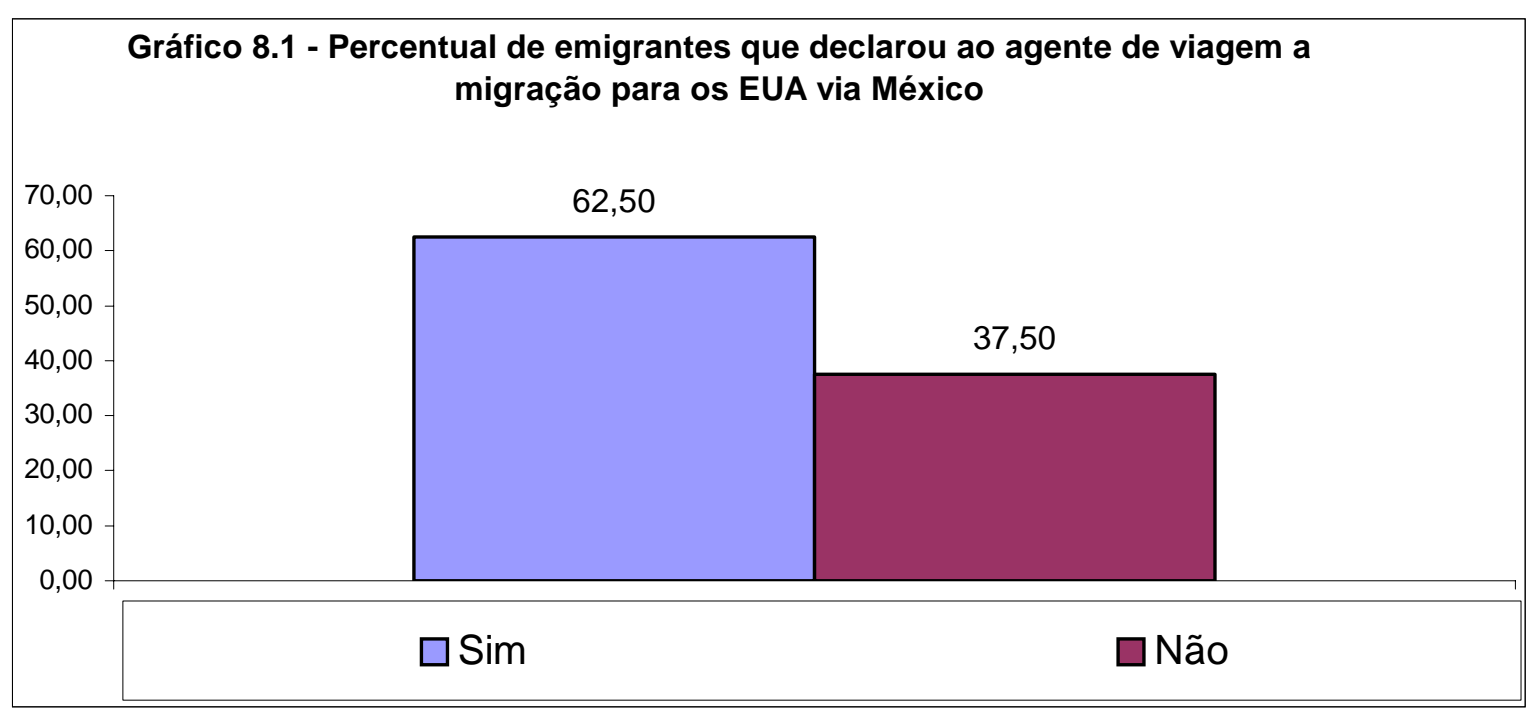

Desse total de pessoas que comunicaram o fato, apenas a metade (50\%) recebeu orientações dos agentes de viagens, no que se refere aos riscos, procedimentos e formas de se comportar na viagem

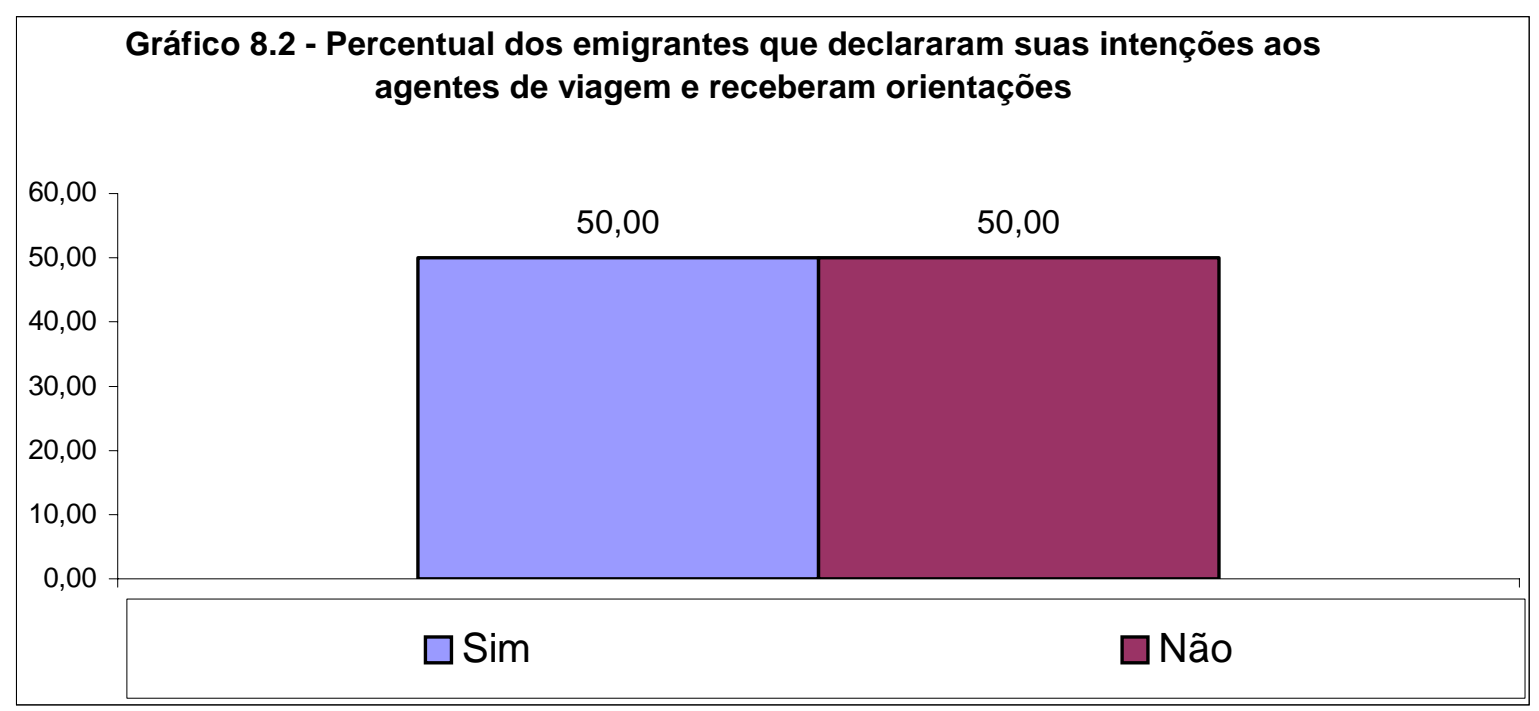

Do total de orientações oferecidas pelos agentes, $62,50 \%$ garantiram que este tipo de viagem é de alto risco e apenas 37,50\% mencionaram que são viagens tranqüilas e seguras. 


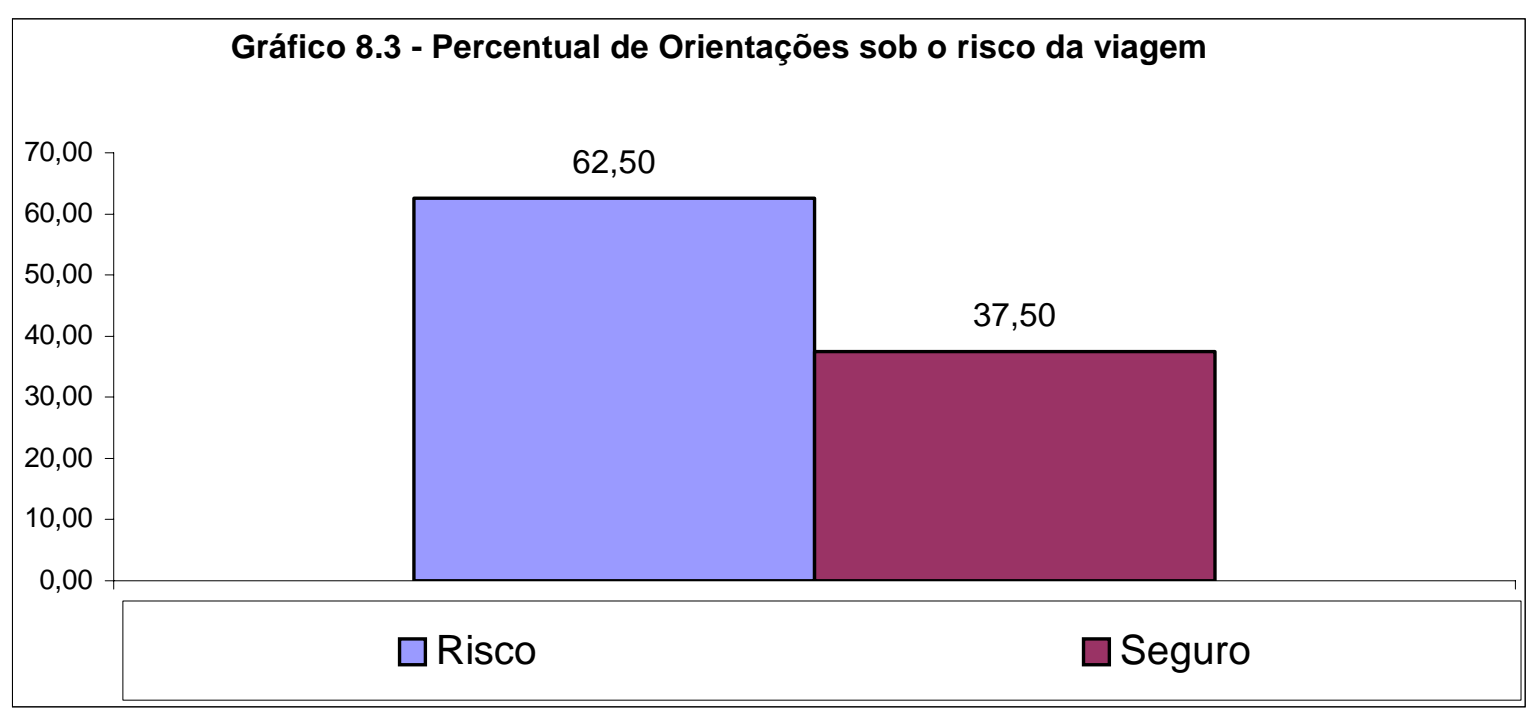

Assim, essa primeira parte de pesquisa indica uma série de fatores que são de alta relevância para o objetivo deste estudo, uma vez que traça o perfil dos clientes em potencial para os fluxos migratórios de Goiânia aos EUA via México. É válido ressaltar que os agentes de viagens estão buscando um nicho altamente complicado e que pode comprometer profundamente seus negócios, dado ao caráter ilícito das viagens. Assim, mesmo que estes estejam fora dos problemas citados, uma vez que os agentes de viagem, teoricamente, apenas emitem os bilhetes, eles estão correndo risco financeiro por comprometerem boa parte das receitas em um mercado que está sujeito às ruínas em pouco prazo. 
Procurando fazer uma análise bivariada entre o perfil apresentado acima, com os proprietários de agências de viagens, serão levados à discussão, suas opiniões e conhecimento sobre este nicho. Neste sentido, o gráfico 1 inicia-se demonstrando que do total de agentes entrevistados, 66,67\% declararam fornecer bilhetes a pessoas que estão com a intenção de migrar para os EUA via México.

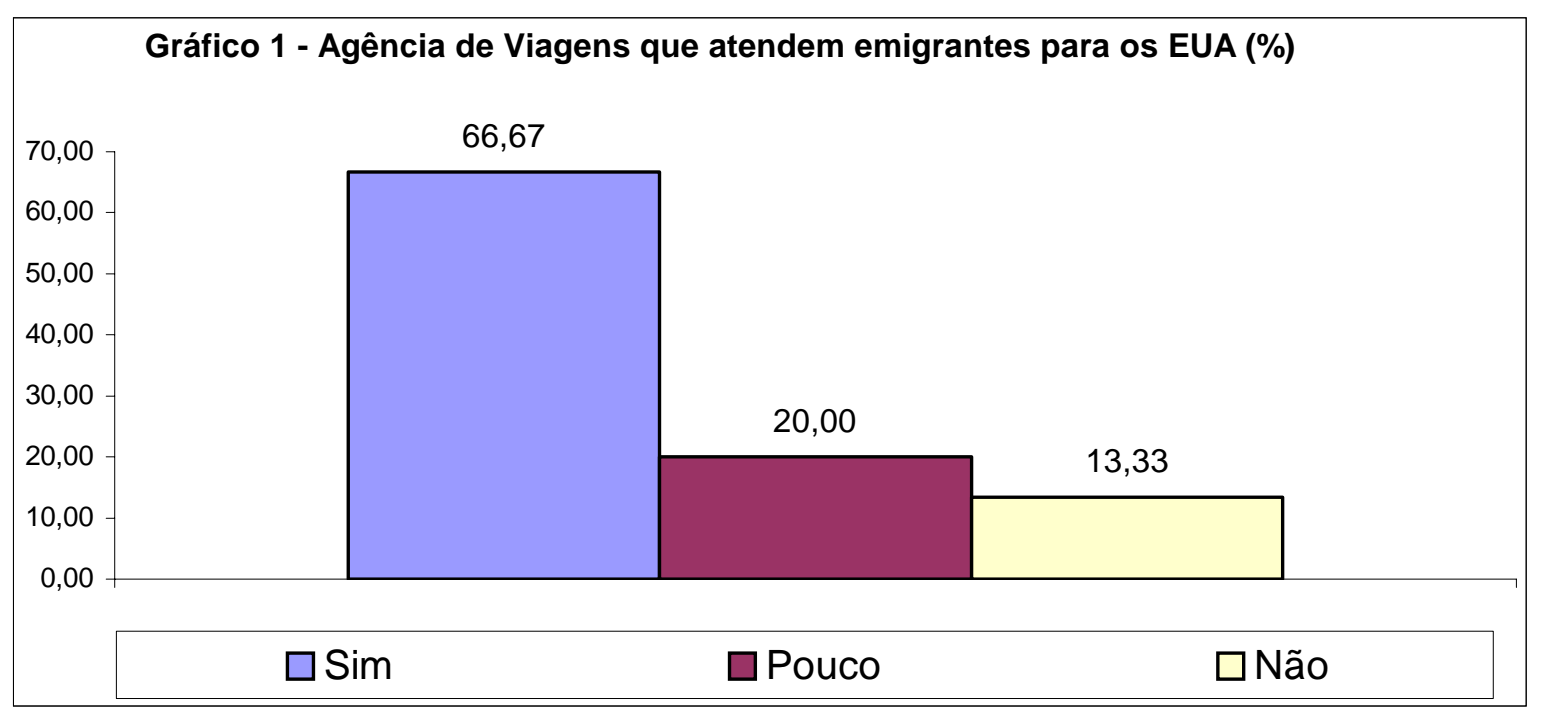

Outro dado que confirma as análises da pesquisa aplicada aos emigrantes, é o de que 40\% das agências de viagem possuem de 21 a 40\% de suas receitas oriundas deste nicho e $20 \%$ possuem de 41 a $60 \%$ de suas receitas também da mesma origem. Ou seja, a maioria destes estabelecimentos estão, totalmente, dependentes deste ramo, e o que é pior, estão com expectativa de crescimento, apesar de não acreditarem que este seja um ramo eterno.

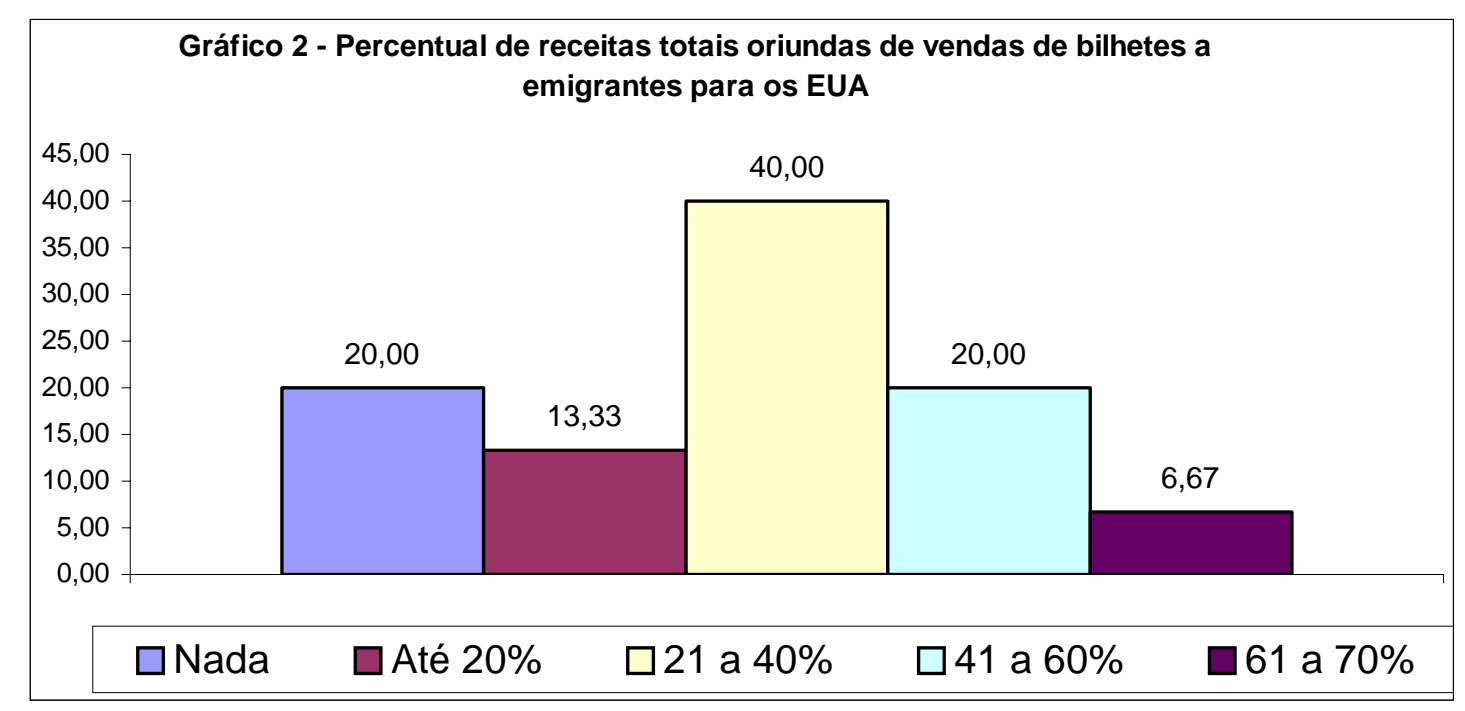


Na questão que versa sobre as orientações necessárias dos agentes aos emigrantes quanto aos riscos de viagem, $40 \%$ destes declararam que somente orientam quando solicitado, e que isso é limitado apenas as suas responsabilidades, ou seja, fizeram questão de se desvencilhar de compromissos com turistas que na verdade tentarão adentrar ilegalmente naquela nação. Além dos que orientam apenas quando solicitado, existem aqueles que orientam sempre, independente ou não de solicitado. O agente Paulo afirma que;

"independente de quem seja, sempre procuro orientar meus clientes que irão para os EUA, principalmente quando percebo que eles farão de forma ilegal. Sei dos riscos, e portanto seria desumano ocultar os fatos, entretanto, faço questão de demonstrar que nossa agência não tem absolutamente nenhuma responsabilidade moral, civil ou jurídica sobre as conseqüências que por ventura possam ocorrer”.

Assim fica clara a realidade, considerando o depoimento acima, onde o agente de viagem se vê na obrigação humana de orientar os futuros emigrantes, mas que, portanto, ele depende diretamente destas migrações para sobreviver como organizações. A questão de que se trata esta pesquisa vai muito além do que meras informações estatísticas. Ele consegue despertar diversas e variadas situações que estão diretamente ligadas a problemas econômicos e sociais do País, ao retratar opiniões de três extratos específicos.

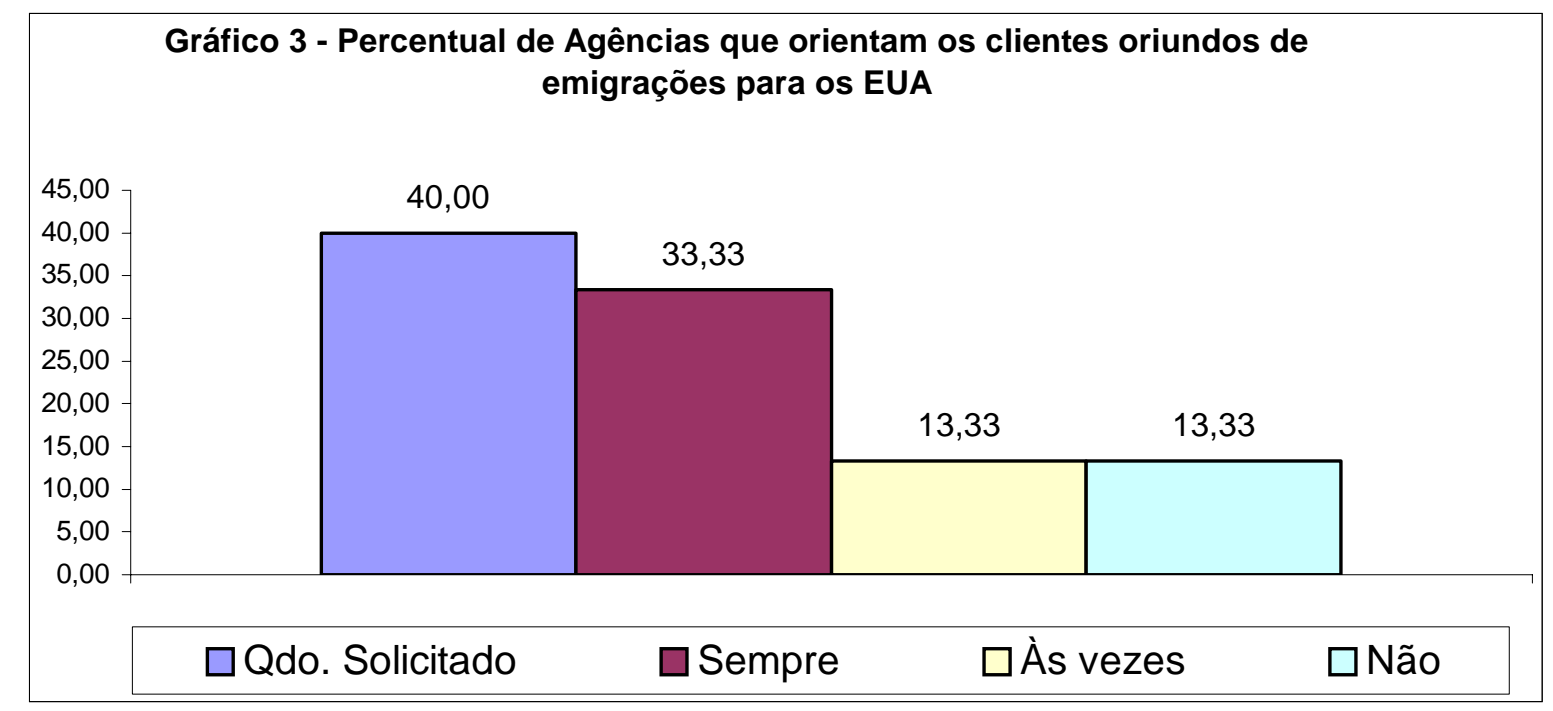

Avaliando a questão das receitas oriundas dessas migrações, o gráfico 4 apresenta o nível de conhecimento e consciência dos agentes de viagens quanto a sazonalidade dessas viagens. Nesse sentido, ficou claro que a grande maioria $(93,33 \%)$ tem conhecimento sobre este fator e acreditam que este nicho é apenas temporário. Isso apresenta um problema, já que 
a receita destas empresas depende, em grandes proporções, das vendas de bilhetes para os emigrantes que rumarão aos estados Unidos via México.

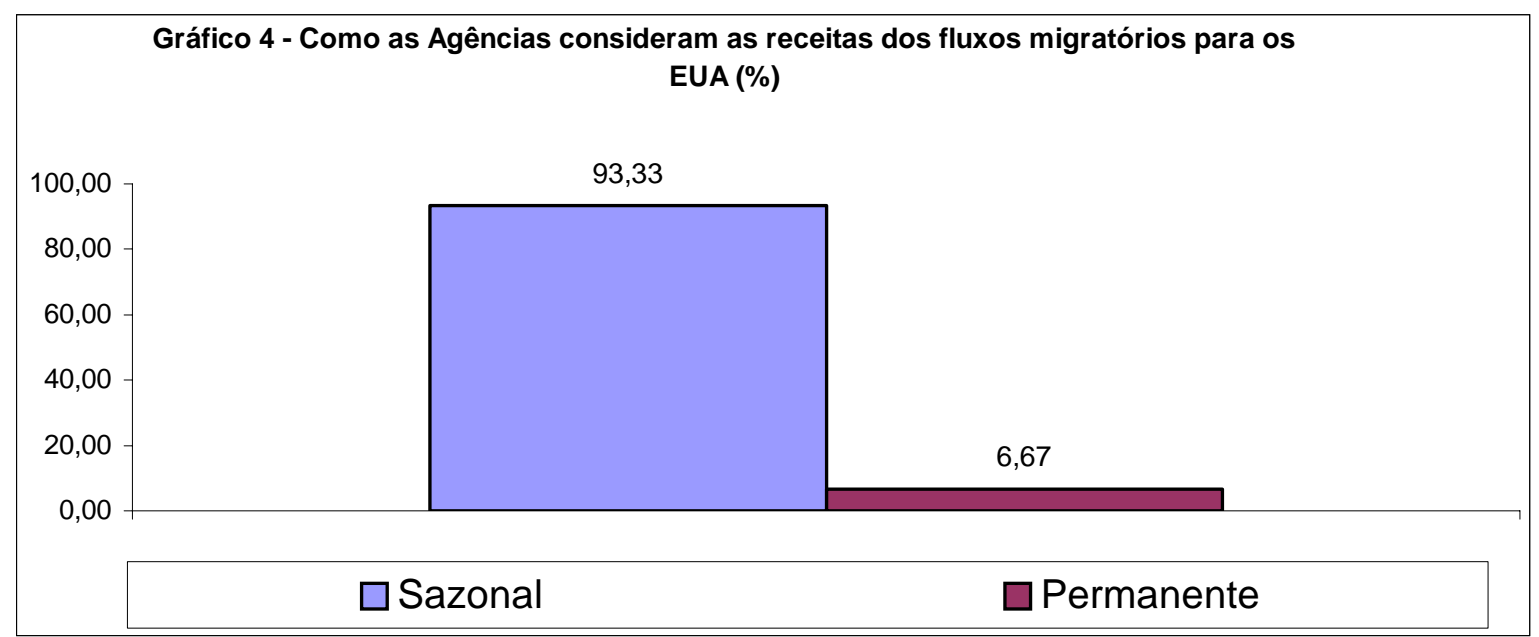

Assim, o gráfico 5.1 é capaz de comprovar que, apesar dos agentes estarem, em sua maioria, dependentes deste nicho de mercado, quase todos (93,33\%) sabem dos riscos que ele oferece. Este fato leva a reflexão sobre o problema da pesquisa, cuja indagação inicial sugeria a investigação de como este mercado influencia na solidez destas empresas, e neste ponto, deduz-se que estes empresários estão altamente vulneráveis, caso ocorra uma decisão por parte dos órgãos competentes em intensificar as fiscalizações. Ademais, a situação por que passa as relações diplomáticas entre as duas nações tem dado demonstração de que, caso ocorra algum acordo de livre movimentação de turistas brasileiros e americanos nos territórios em discussão, certamente novos e mais modernos mecanismos serão implementados para favorecer o controle e fiscalização.

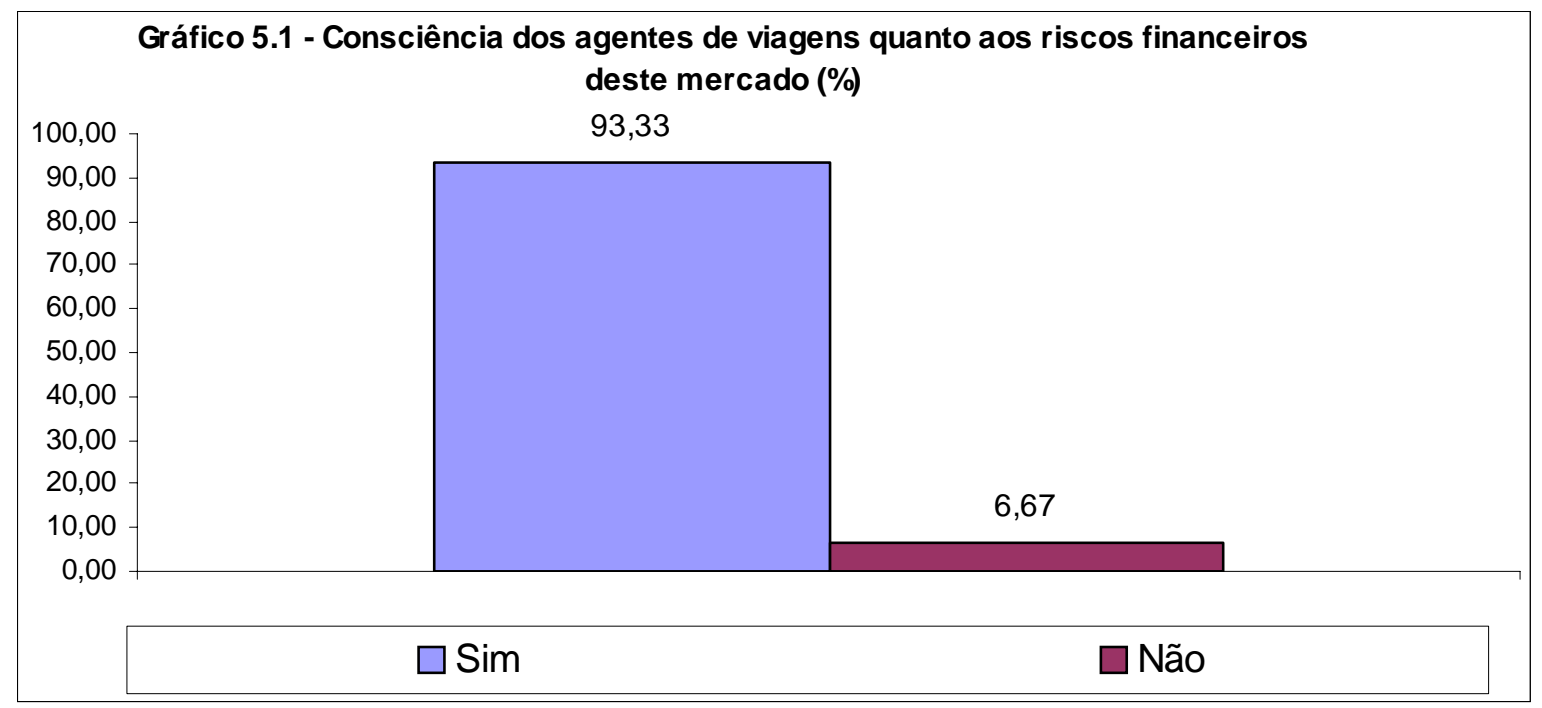


Considerando a reflexão sobre os resultados do gráfico 5.1, procurou-se também verificar, conforme gráfico 5.2, se os entrevistados estão investindo em outros nichos de mercado dentro do setor de agências de viagem. Comprovou-se que apenas $40 \%$ dos entrevistados operam fora do seu mercado habitual. O que é um resultando alarmante para o setor frente aos riscos já apresentados, ficando os 60\% restantes, dependentes apenas de receitas oriundas de um mercado de alto risco e sazonal.

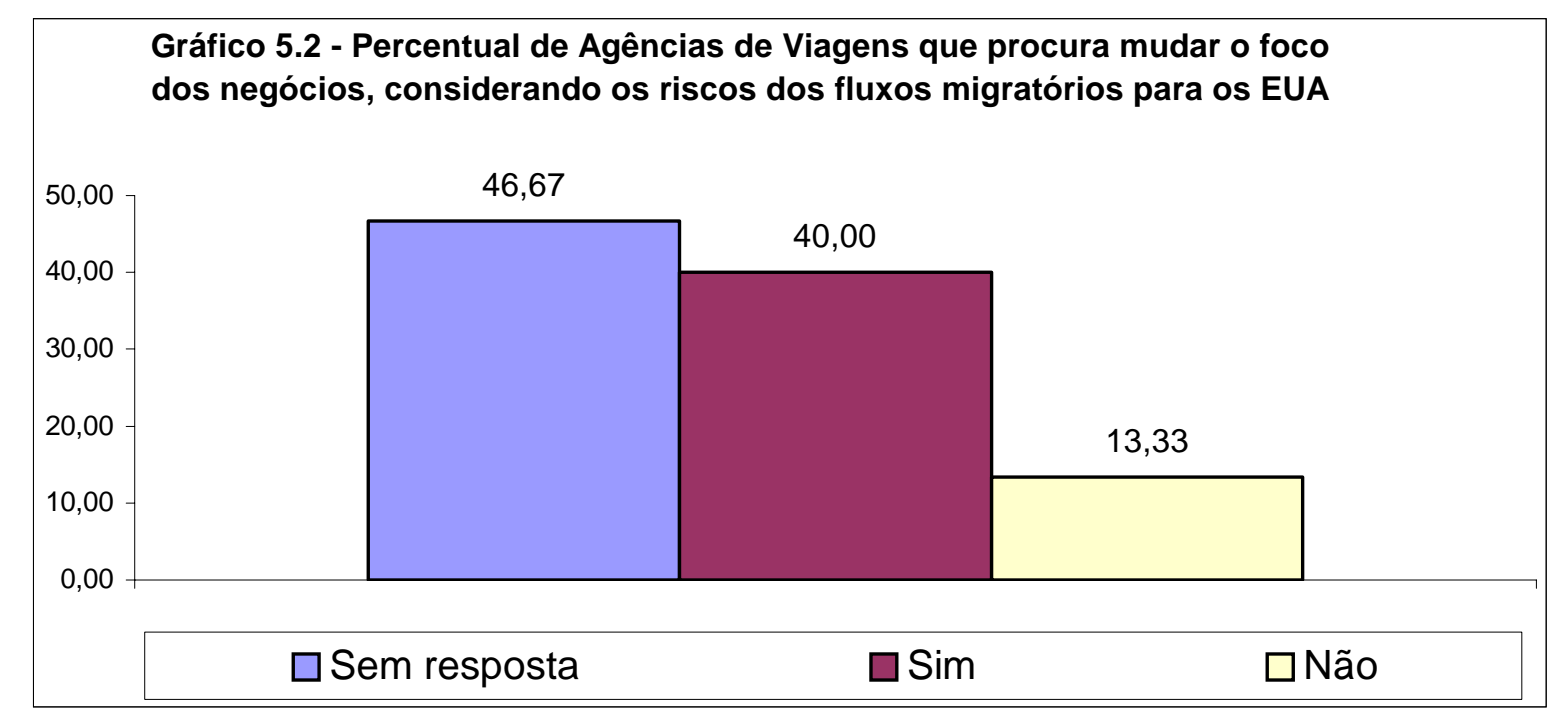

No que se refere as estatísticas oficiais, os agentes de viagem entendem que os casos de migrações ilegais são válidas como números conforme demonstra o percentual de 86,67\% do gráfico 6. De acordo com o agente Pereira,

\begin{abstract}
"quando minha agência realiza uma venda de passagens, a Embratur naturalmente terá acesso a estes dados, pois representa um gasto de um turista com viagens para o exterior, uma vez que, não é possível informar quando os casos são de migrações ilegais. Assim, acredito ser importante ter este registro para se poder controlar a mercado de turismo internacional.”
\end{abstract}

Essa resposta deixa claro que há um grande equívoco, uma vez que isso não representa circulação de capital para o turismo, mas sim, para migração de cidadãos brasileiros para outros países. Segundo dados da Embratur, em 2002 foram contabilizados os seguintes números de brasileiros que saíram a turismo para o exterior: 539.711 para a América do Norte; 471.885 para a América do Sul e 8.320.320 para a Europa. Neste sentido, comparando esses dados ao percentual médio de receitas que os agentes declararam faturar para o mercado de migração aos EUA, mais da metade destes números seriam estatísticas inválidas. Assim, ainda paira a dúvida sobre como os órgãos de turismo têm conduzido esses dados, pois, sua 
falta de confiabilidade interferirá em diversas áreas, deste o dimensionamento do desenvolvimento turístico no país, até os estudos, projetos e pesquisas do setor exploratório de viagens.

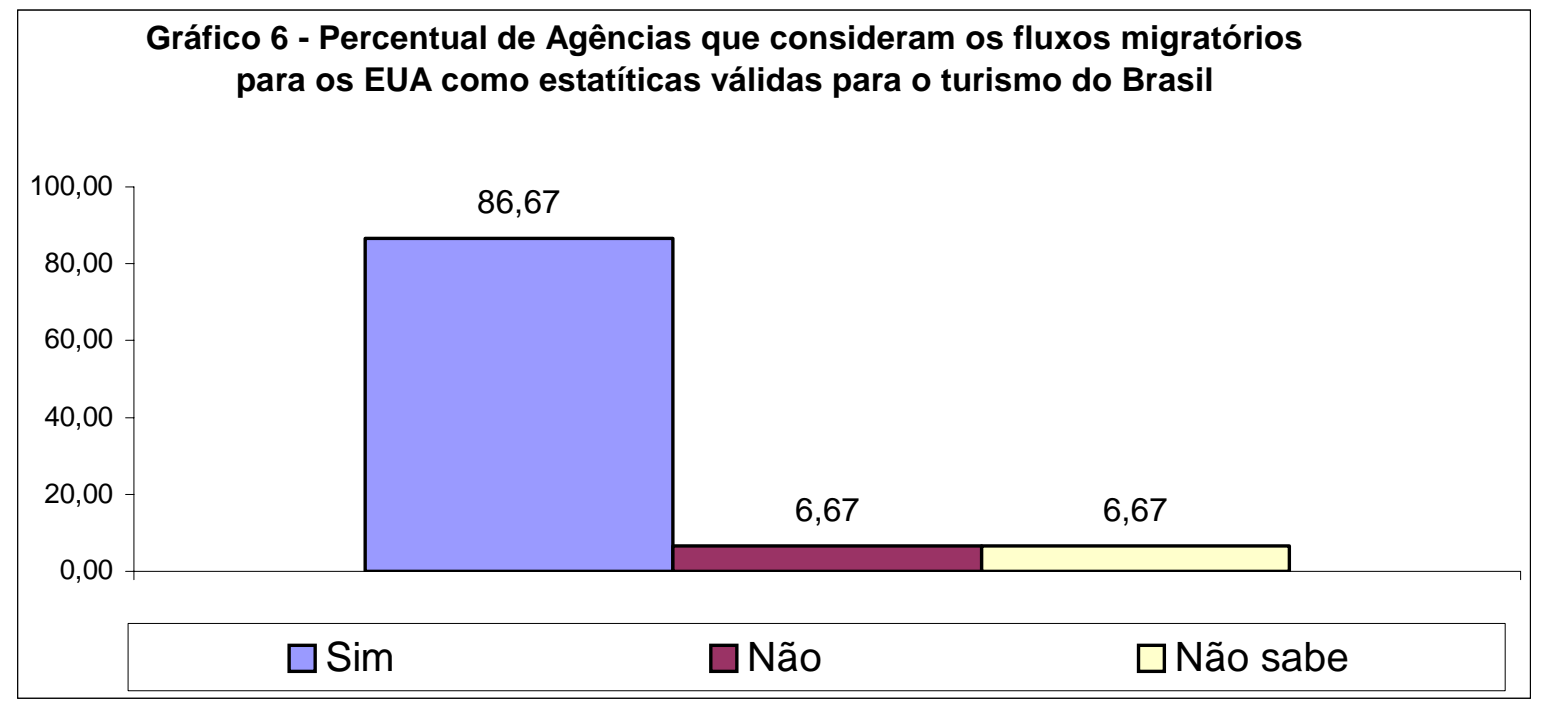

Finalmente, cumprindo o ciclo da análise, serão apresentados os resultados de uma das partes mais interessantes do estudo, a entrevista com “coyotes”. Essas pessoas são os principais meios pelos os quais grande parte dos cidadãos decidem arriscar nas migrações ilegais para os Estados Unidos, uma vez que elas oferecem oportunidades de favorecer todo o trajeto sem que o brasileiro tenha que retirar seu passaporte. Por outro lado, também representam grande mágoa e desestabilização para os que tem suas tentativas frustradas, vez que não há nenhuma garantia, nem tão pouco meios de localiza-los e recuperar o dinheiro investido, como demonstra a questão 1, onde se inquiriu sobre as garantias oferecidas aos elementos que contratam o serviço de migração clandestina. Dos 3 "coyotes” entrevistados, todos foram categóricos ao afirma que não há garantia ou contrato escrito, mais apenas verbal e em alguns casos, garante-se as passagens aéreas. Eles mencionam que já possuem um nome no mercado, e portanto, não há necessidade destas garantias.

Segundo José (nome fictício) “eu não preciso garantir nada pra ninguém, o sujeito que quer migrar para os Estados Unidos tem duas opções, ou confia em minha palavra ou não viaja. Raramente tive problemas de retorno de clientes, sendo que dos casos ocorridos eu consegui fazer a travessia na segunda tentativa. Jamais eu faria um contrato escrito, pois não sou otário.”

No que se refere ao lucro por eles angariados nestas operações, dos 10.500 dólares cobrados por pessoa, a maioria afirmou ficar apenas com $10 \%$ do valor. O restante da quantia 
é dividido em subornos aos demais envolvidos, os quais não foram revelados em quantos são. Na oportunidade, perguntou-lhes se consideravam "traficantes de seres humanos”, o que lhes causou um impacto e gerou respostas bem defensivas do tipo "vai quem quer”, "não engano ninguém”, “tenho meus negócios, sou empresário e apenas ajudo as pessoas” e surpreendentemente, um dos entrevistados revelou ser agente de viagem. Assim, nota-se que este filão é explorado, como várias outros ramos do Brasil, como oportunidade de ganhar dinheiro às custas da ilegalidade e da dificuldade alheia, o que não revela uma estatística positiva.

No que se refere à quantidade de pessoas que cada um destes elementos encaminham para os EUA via México, anualmente, tem-se uma média de 700 brasileiros. Mesmo que, segundo a entrevista com os emigrantes, revelou-se que estes conhecem vários casos de tentativas frustradas, os "coyotes" afirmam que elas são raras e quando isso ocorre, eles garantem o reenvio.

Procurando explorar os tipos de pessoas envolvidas nestas operações, perguntoulhes como eram compostas suas equipes, entre brasileiros, mexicanos e americanos. Dois dos entrevistados não responderam a questão, vez que ela é comprometedora; o terceiro, apenas revelou que é "uma galera grande”, onde se têm menos brasileiros e mais mexicanos e americanos, revelando assim, que este nicho também é interessante para os outros países e que, inclusive os norte-americanos, são maioria nestas operações.

Quanto ao ponto de vista dos “coyotes" sobre a constância desses fluxos migratórios, dois deles acreditam que eles são perenes enquanto houver pessoas para pagar o valor. O terceiro entrevistado acredita que não; que é apenas uma oportunidade com tempo determinado para acabar. Outro ponto que era expectativa na entrevista, era identificar se havia relação de propina entre estes elementos e o governo brasileiro, o que surpreendentemente revelou que não há. Entretanto, apresentaram-se indícios de que há sim, mas com os governos dos outros países, conforme um deles informa: "não gasto grana com brasileiros, apenas com mexicanos e americanos, sendo que com os americanos o gasto é bem maior.”

Ao se verificar a relação entre agentes de viagens e “coyotes”, a maioria afirmou que mantém fidelidade com alguns em troca de comissão, ou seja, os agentes de viagem mantêm acordos de ganhos mútuos por indicação, o que revela mais uma preocupação quanto 
a sanidade destas empresas, vez que se demonstram amplamente dependentes deste ramo de negócios. Segundo José "tenho meus parceiros (agentes de viagem) de confiança. Eu pego e garanto um percentual para que ele mande pra mim clientes que pretendem ir para os EUA e não possuem condições de tirar o passaporte. Atualmente mantenho contato com quatro agentes.”

Outro fato revelado, é que estes atravessadores atendem pessoas do País inteiro. Inclusive, de outros países, como Portugal, sendo que todas as passagens aéreas são compradas nas agências de Goiânia. Um dos entrevistados fez a seguinte colocação: “despacho gente até do planeta marte que queira ir para os Estados Unidos. Não fico escolhendo só gente de Goiânia, meu negócio é ganhar dinheiro e para fazer isso é preciso atender todos 


\section{CONCLUSÃO}

Assim, a pesquisa aplicada explora a amplitude em que se encontra o nicho em estudo e qual sua representatividade como estatística oficial, revelando um controle totalmente irreal, porém difícil de ser dimensionado, pois, não se sabe ao certo a quantidade de atravessadores existentes no País, nem tão pouco a quantidade de pessoas que, anualmente tem migrado para os Estados Unidos ilegalmente. Apenas se sabe que são muitos, considerando a atual situação revelada pelos meios de comunicação sobre o número de brasileiros que hoje se encontram presos na fronteira, aguardando deportação para o Brasil.

No que se refere aos agentes de viagens, principal foco da pesquisa, vê-se como um setor que está em eminência de quebra caso ocorra uma intensificação das fiscalizações nos dois países, revelando que não são muitos os empresários deste ramo que estão agregando novos nichos de mercado como forma de proteção dos negócios. Infelizmente, estes são movidos pela oportunidade súbita de ganho de capital fácil pelo número crescente de pessoas que estão decidindo por tentarem outras oportunidades de vida fora do País. Além disso, a pesquisa revela que estes fluxos são constantes durante o ano e que há todo um esquema montado entre pessoas do Brasil, México e Estados Unidos para garantir todo ardoroso trajeto até o território norte-americano.

Diante deste panorama, fomenta-se algumas questões: qual será o futuro destas pessoas que migram para os EUA? Quando o governo brasileiro tomará ciência deste problema e interferirá em suas causas? Até quando os agentes de viagem dependerão deste nicho?

Essas questões somente serão respondidas quando a causa for tomada com seriedade por todos os órgãos responsáveis por esta área e quando o País passar a fomentar 
um turismo real, em que será possível investir em tecnologia suficiente para identificar estes problemas, combater os atravessadores e gerar melhores condições de controle e proteção do turismo nacional e internacional. Ao mesmo passo, haveria uma contenção natural se houvesse uma política pública que gerasse o crescimento econômico do país, diminuísse as desigualdades e quebrasse o paradigma cultural atualmente incidente. Entretanto, enquanto houver extremas desigualdades, falta de oportunidade de emprego e vida digna, talvez esse ainda seja o melhor caminho a ser seguido pelos oportunistas, pelos agentes de viagem e por nossos compatriotas. 


\section{REFERÊNCIAS BIBLIOGRÁFICAS}

ÁLVARES, Paulo de Tarso Tonelli Teixeira. Administração Mercadológica III. Universidade Salgado de Oliveira. Goiânia, 2000.

PARRA, Filho Domingos. Apresentação de Trabalhos Científicos: monografias, TCC, Teses e dissertações. 3. ed. São Paulo: Futura, 2000.

ROESCH, Sylvia Maria Azevedo. Projetos de estágio do curso de administração: guia para pesquisas, projetos, estágios e trabalhos de conclusão de curso. São Paulo: Atlas, 1996.

BRITO, Fausto. Ensaio sobre as migrações internacionais no desenvolvimento do capitalismo. Artigo. 1995.

CANO, Wilson. Reflexões sobre o Brasil e a nova (des)ordem mundial. Campinas, Editora da Unicamp, 1993.

FNUAP. A situação da população mundial 1993. FNUAP, 1993.

GALLETI, Roseli. Imigração recente para a metrópole paulistana. Comunicação apresentada no seminário Contexto Geral das Migrações Internacionais, Campinas, Fecamp/Unicamp, 1995.

HEINZ, Fassmann e MUNZ, Rainer. "European east-west migration, 1945-1992". International Migration Review, vol. XXVIII, n. 3, outono, 1994.

HOBSBAWM, Eric J. The age of capital. Londres, Weidenfeld \& Nicolson, 1977.

LENIN, V. I. Imperialismo, estádio superior do capitalismo. Coimbra, Editora Centelha, 1973.

LEVY, Maria Stella. “O papel da migração internacional na evolução da população brasileira 1872-1972”. Revista de Saúde Pública, n. 8 (suplemento), 1974.

NOVAIS, Fernando. Portugal e Brasil no Antigo Sistema Colonial (1777-1808). São Paulo, Hucitec, 1979. 
REYDON, Bastiaan e PLATA, Ludwig. “As migrações e o mercado de terras agrícolas no Cone Sul”. In: PATARRA, Neide (coord.), Emigração e Imigração Internacionais no Brasil Contemporâneo, Campinas, FNUAP/Editora da Unicamp, 1995.

ROSSINI, Rosa Ester. “À procura das origens ou a expectativa do enriquecimento rápido: o exemplo dos ‘dekasseguis’ do Brasil em direção ao Japão”. Revista Brasileira de Estudos de População, vol. 9, n. 2, jul.-dez., 1992, pp.200-4.

SALES, Teresa. "Novos fluxos migratórios da população brasileira”. Revista Brasileira de Estudos de População, vol. 8 , ns. 1-2, jan.-dez., 1991, pp.21-32.

WRIGLEY, C. Population and history. World University Library, 1979.

Site Imigrantes. O Mundo. Disponível em < http://imigrantes.no.sapo.pt/page4.html>, capturado em 20 jan 2004. 
ANEXOS - QUESTIONÁRIOS APLICADOS À PESQUISA 